\title{
Sinter Hardening PM Steels Prepared through Hybrid Alloying*
}

\section{Herstellung von sinterhärtenden pulvermetallurgischen Stählen durch Hybridlegierungstechnik}

\section{Abstract/Kurzfassung}

In powder metallurgy (PM), there are several ways of introducing alloying elements into a PM material in order to adjust a certain alloying element content. Each alloying route has its advantages and disadvantages. Master alloys (MA), powders with a high content of typically several alloying elements, can be added in small amounts to a base powder, especially to introduce oxygen sensitive elements such as $\mathrm{Cr}$, Mn, and $\mathrm{Si}$. In addition, the master alloy can be designed in such a way that a liquid phase is formed intermediately during the sintering process to improve the distribution of alloying elements in the material and to accelerate homogenization. In this study, such master alloys were combined with pre-alloyed base powders to form hybrid alloyed mixtures with the aim of improving the material's sinter hardenability. The hybrid alloys were compared with mixtures of master alloy and plain Fe as reference material. The sinter hardenability of all materials was determined by generating CCT diagrams recorded with 13 different cooling rates. These were verified by metallographic cross-sections of specimens treated at common cooling rates of 3 and $1.5 \mathrm{~K} / \mathrm{s}$ and subsequent hardness measurements of the microhardness (HV 0.1) of the microstructural constituents and the apparent hardness (HV 30).

Keywords: PM-steel, CCT diagrams, masteralloy, pre-alloyed powder, microstructure, hardenability
In der Pulvermetallurgie (PM) gibt es mehrere Möglichkeiten Legierungselemente in ein PM-Material einzubringen, um einen bestimmten Legierungselementgehalt einzustellen. Jede Legierungsroute hat ihre Vor- und Nachteile. Master Alloys, Pulver mit hohem Gehalt an typischerweise mehreren Legierungselementen, können einem Basispulver in geringen Mengen zugesetzt werden, insbesondere um sauerstoffempfindliche Elemente wie Cr, Mn und Si einzubringen. Darüber hinaus kann das Master Alloy so gestaltet werden, dass sich während des Sinterprozesses intermediär eine flüssige Phase bildet, um die Verteilung der Legierungselemente im Werkstoff zu verbessern und die Homogenisierung zu beschleunigen. Derartig gestaltete Master Alloys wurden in dieser Studie mit vorlegierten Basispulvern zu hybridlegierten Mischungen kombiniert, mit dem Ziel, die Sinterhärtbarkeit des Materials zu verbessern. Verglichen wurden die Hybridlegierungen mit Mischungen von Master Alloy und reinem Fe als Referenzmaterial. Die Sinterhärtbarkeit aller Materialien wurde mittels ZTU-Diagrammen bestimmt, die mit 13 unterschiedlichen Kühlraten aufgezeichnet wurden. Verifiziert wurden diese durch metallographische Schliffe an bei in der Sinterindustrie gängigen Kühlraten von 3 und 1,5 K/s sintergehärteten Proben und darauf ausgeführten Härtemessungen der Mikrohärte (HV 0,1) der Gefügebestandteile als auch der integralen Härte (HV 30).

Schlüsselwörter: PM-Stahl, ZTU-Diagramme, vorlegierte Pulver, Master Alloys, Mikrostruktur, Härtbarkeit

Authors/Autoren: Dipl.-Ing. Stefan Geroldinger, Assistant Prof. Raquel de Oro Calderon, PhD MSc, Associate Prof. Dipl.-Ing. Dr. techn. Christian Gierl-Mayer, Univ. Prof. Dipl.-Ing. Dr. techn. Dr.h.c.mult. Herbert Danninger, TU Wien, Getreidemarkt 9, 1060 Wien, stefan.geroldinger@tuwien.ac.at (corresponding author/Kontakt)

HOW TO CITE THIS ARTICLE: S. Geroldinger et al.: Sinter Hardening PM Steels Prepared through Hybrid Alloying. HTM J. Heat Treatm. Mat. 76 (2021) 2 , pp. 105-119, DOI:10.1515/htm-2020-0007

¿ Open Access. @ 2020 Stefan Geroldinger, published by De Gruyter. (сc) BY This work is licensed under the Creative Commons Attribution 4.0 International License. 


\section{Introduction}

Ferrous powder metallurgy precision parts are manufactured for a wide range of applications, their main benefits being excellent reproducibility of dimensions and properties and efficient utilization of material and energy. With increasing demands on lightweight constructions, PM parts also have to be reduced in dimensions and mass which, in combination with increasing mechanical loads, leads to higher demands on the strength of the material. Therefore, new alloying systems are necessary which in particular offer excellent heat treatment response [1].

The trend towards new alloy systems is also enhanced by economic and ecological considerations. Whereas classical PM steels for precision parts are usually alloyed with $\mathrm{Cu}$ sometimes combined with $\mathrm{Ni}$ and/or Mo, today more cost-efficient alloy elements such as $\mathrm{Cr}, \mathrm{Mn}$ and $\mathrm{Si}$ are also being investigated for sintered steels, where the high oxygen affinity of these elements is much more critical than in the case of wrought steels. Another economic factor is the cost of heat treatment as a separate processing step. Therefore, sinter hardening has been introduced on a large scale in the production of PM, i.e. a process in which the parts are quenched with cold inert gas immediately after leaving the high temperature zone of the sintering furnace. This results in cooling rates of typically $2-3 \mathrm{~K} / \mathrm{s}$ in a fully loaded furnace and thus significantly slower than e. g. oil quenching. On the other hand, this is a much cleaner process, since the parts are not contaminated with oil, which is important regarding the open porosity of virtually all PM precision parts. The slower cooling must be compensated for by suitable alloying, and here the appropriate combination of several alloying elements can be particularly beneficial.

In contrast to ingot metallurgy, in PM not only the selection of alloying elements but also the alloying route is a parameter that influences the properties of the final product. In Figure 1 the alloying routes commonly used in PM are shown schematically. Pre-alloyed powders exhibit a homogeneous distribution of alloying elements, but due to solid solution hardening, the powders are harder and thus less compactible than plain elemental powders in each particle $[2,3]$. It proved difficult to sinter harden steels from most pre-alloyed powders under standard conditions without addition of further alloying elements, except for those powders with fairly high alloy element content, which multiplies the cost and the

\section{Einführung}

Pulvermetallurgische (PM) Präzisionsteile werden für eine Vielzahl von Anwendungen hergestellt, wobei die Hauptvorteile in der ausgezeichneten Reproduzierbarkeit von Abmessungen und Eigenschaften sowie der effizienten Nutzung von Material und Energie liegen. Mit steigenden Anforderungen an den Leichtbau müssen auch PM-Teile in Abmessungen und Masse reduziert werden, was in Verbindung mit steigenden mechanischen Belastungen $\mathrm{zu}$ höheren Anforderungen an die Festigkeit des Materials führt. Daher sind neue Legierungssysteme notwendig, die insbesondere ein hervorragendes Wärmebehandlungsverhalten bieten [1].

Der Trend zu neuen Legierungssystemen wird auch durch ökonomische und ökologische Überlegungen verstärkt. Während klassische PM-Stähle für die Präzisionsteile meist mit $\mathrm{Cu}$ legiert werden, teilweise in Kombination mit Ni und/oder Mo, werden heute kostengünstigere Legierungselemente wie $\mathrm{Cr}, \mathrm{Mn}$ und $\mathrm{Si}$ auch für Sinterstähle untersucht, bei denen die hohe Sauerstoffaffinität dieser Elemente wesentlich kritischer ist als bei schmelzmetallurgischen Stählen. Ein weiterer wirtschaftlicher Faktor sind die Kosten der Wärmebehandlung als separater Nachbehandlungsschritt. Daher wurde in der Produktion von PM-Teilen die Sinterhärtung in großem Maßstab eingeführt, d. h. ein Prozess, bei dem die Teile unmittelbar nach dem Verlassen der Hochtemperaturzone des Sinterofens mit kaltem Inertgas abgeschreckt werden. Dies führt zu Abkühlgeschwindigkeiten von typischerweise 2-3 K/s in einem voll beladenen Ofen und ist damit deutlich langsamer als z. B. bei der Ölabschreckung. Andererseits handelt es sich dabei um einen wesentlich saubereren Prozess, da die Bauteile nicht mit Öl in Kontakt kommen, was gerade im Hinblick auf die offene Porosität praktisch aller PM-Präzisionsteile von Bedeutung ist. Die langsamere Abkühlung muss durch eine geeignete Legierungswahl kompensiert werden. Hier kann die geeignete Kombination mehrerer Legierungselemente vorteilhaft sein.

Im Gegensatz zur Schmelzmetallurgie ist in der PM nicht nur die Auswahl der Legierungselemente, sondern auch die Route, über die legiert wird, ein Parameter, der die Eigenschaften des Endprodukts beeinflusst. In Bild 1 sind die in der PM gängigen Legierungsrouten schematisch dargestellt. Vorlegierte Pulver weisen eine homogene Verteilung der Legierungselemente auf, aber die Pulver sind aufgrund der Mischkristallhärtung in jedem Partikel härter als Elementarpulver, was zu einer schlechteren Verpressbarkeit führt [2,3]. Es erwies sich als schwierig, Sinterstähle aus den meisten vorlegierten Pulvern unter Standardbedingungen und ohne Zugabe von zusätzlichen Legierungselementen zu sin-

Fig. 1. Schematic representation of common alloy routes in powder metallurgy: 1. elemental powder blend 2. master alloy 3. pre-alloyed powder 4. diffusion alloyed powder 5. coated powder based on representations in [21] and [22]

Bild 1. Schematische Darstellung der gängigen Legierungsrouten in der Pulvermetallurgie: 1. Elementarpulvermischung 2. Master Legierungs-Route 3.Vorlegierung 4. Diffusionslegiertes Pulver 5. beschichtetes Pulver basierend auf Darstellungen in [21] und [22]

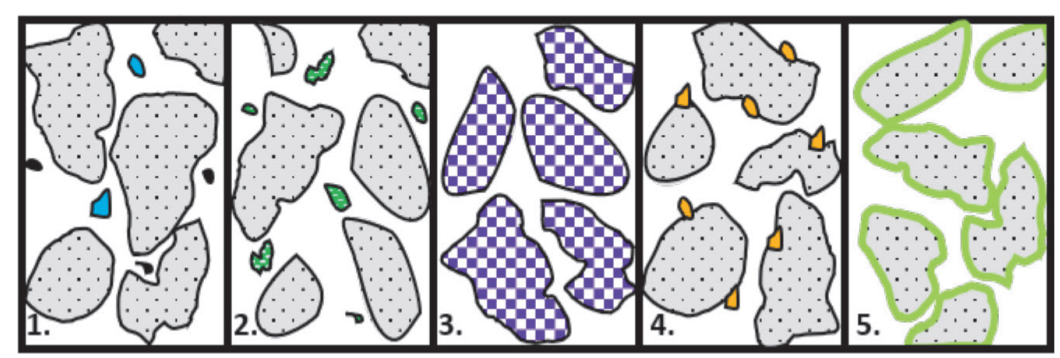


compaction problem [4]. For adding these further elements, master alloys are an attractive variant. A master alloy (MA) is a powder with a high content of alloying elements, which typically contains several elements combined in one powder. MAs are used in small amounts (usually $<5 \mathrm{wt} . \%$ ) to add all the necessary major alloying elements at once to a base material. MAs turned out to be particularly well suited to add oxygen-sensitive alloying elements, such as $\mathrm{Cr}, \mathrm{Mn}$ and $\mathrm{Si}$ [5-8] and due to the relatively small amount of MAs added, the compactibility is only marginally reduced $[9,10]$. Furthermore, by selecting suitable compositions for the master alloys e. g. by using thermodynamic simulations -, low-melting variants of MAs can be defined, which form a transient liquid phase in the early stages of sintering and thus accelerate the microstructural homogenization. By implementing new atomization techniques such as e.g. high pressure water atomization, fine MA powders containing $\mathrm{Fe}, \mathrm{Si}, \mathrm{C}, \mathrm{Cr}$ and/or $\mathrm{Mn}$ with low oxygen content can be produced today [11]. These MAs were further modified to improve liquid phase formation, infiltration behaviour and alloying element content compared to previous studies [12].

In the present study MAs with compositions defined in [12] were combined with plain Fe base powder and pre-alloyed base powders containing $\mathrm{Cr}$ and/or Mo [4]. CCT diagrams of all hybrid alloyed mixes (MA with pre-alloyed base powder) and the reference material ( $\mathrm{MA}+$ plain $\mathrm{Fe}$ ) were generated and compared with regard to hardenability and microstructure in order to optimize the combination of alloying elements and alloying routes (hybrid alloying) with regard to sinter hardening response of the material. In this context it should be pointed out that a certain degree of microstructural homogeneity is required for plotting representative CCT diagrams. For pronouncedly heterogeneous materials such as the "Distaloy" type of sintered steels [13] in which e. g. ferrite, pearlite, martensite and retained austenite can be present in one specimen close to one another, CCT diagrams are at best extremely blurred, at worst meaningless. Therefore, in the present study, both the MAs and the sintering conditions were selected to produce a sufficiently homogeneous material.

\section{Materials and methods}

Powder mixes of about $1 \mathrm{~kg}$ batch mass were prepared from a base powder $+4 \mathrm{wt} . \% \mathrm{MA}$ and elemental $\mathrm{C}$ as natural graphite (total C content of the mix $0.6 \mathrm{wt} . \%$ ); the starting powders are listed in Table 1. The powders were blended in a Turbula mixer for $10 \mathrm{~min}$, according to the standard procedure in the industry. Charpy impact test specimens ISO 5754 were pressed with $600 \mathrm{MPa}$ and die terhärten, ausgenommen jene Pulver, die bereits einen eher hohen Gehalt an Legierungselementen aufweisen, was jedoch die Kosten und das Kompaktierungsproblem vervielfacht [4]. Für die Zugabe dieser zusätzlichen Legierungselemente sind Master Alloys eine attraktive Variante. Ein Master Alloy (MA) ist ein Pulver mit einem hohen Gehalt an Legierungselementen, das typischerweise mehrere verschiedene Legierungselemente in einem Pulver vereint. MAs werden in geringen Mengen (üblicherweise $<5$ Gew.- $\%$ ) verwendet, um alle notwendigen Legierungselemente auf einmal zu einem Basispulver hinzuzufügen. MAs erweisen sich insbesondere als gut geeignet, um sauerstoffempfindliche Legierungselemente wie Cr, Mn und Si einzubringen [5-8] und aufgrund der relativ geringen Menge an MAs, die zugegeben wird, wird die Verpressbarkeit nur geringfügig herabgesetzt $[9,10]$. Darüber hinaus können durch die Wahl geeigneter Zusammensetzungen für die Vorlegierungen - unterstützt z. B. durch thermodynamische Simulationen - niedrigschmelzende Varianten von MAs definiert werden, die in frühen Stadien des Sinterns eine intermediäre flüssige Phase bilden und damit die Gefügehomogenisierung sehr stark beschleunigen. Durch den Einsatz neuer Verdüsungstechniken wie z. B. Hochdruckwasserverdüsung können heute feine MAPulver mit Fe, Si, C, Cr und/oder Mn mit niedrigem Sauerstoffgehalt hergestellt werden [11]. Diese MAs wurden hier weiter modifiziert, um die Flüssigphasenbildung, das Infiltrationsverhalten und den Gehalt an Legierungselementen im Vergleich zu früheren Studien zu verbessern [12].

In dieser Studie wurden MAs mit den in [12] definierten $\mathrm{Zu}$ sammensetzungen mit Reineisen-Basispulvern und vorlegierten Basispulvern, die $\mathrm{Cr}$ und/oder Mo enthalten, kombiniert [4]. Von allen Hybridlegierungen (MA kombiniert mit vorlegiertem Basispulver) und dem Referenzmaterial (MA + reines $\mathrm{Fe}$ ) wurden ZTU-Diagramme erstellt und hinsichtlich Härtbarkeit und Gefüge verglichen, um die Kombination von Legierungselementen und Legierungsrouten (Hybridlegierungstechnik) in Hinblick auf das Sinterhärteverhalten zu optimieren. An dieser Stelle muss auch darauf hingewiesen werden, dass, um repräsentative ZTU-Diagramme erstellen zu können, ein gewisser Grad an Homogenität der Legierungselementverteilung erforderlich ist. Für dezidiert heterogene Werkstoffe, wie z. B. Sinterstähle des Typs „Distaloy“ [13], bei denen z. B. Ferrit, Perlit, Martensit und Restaustenit in einer Probe nebeneinander vorliegen können, sind ZTU-Diagramme bestenfalls extrem unscharf, im schlimmsten Fall nicht aussagekräftig. Daher wurden in der vorliegenden Studie sowohl die MAs als auch die Sinterbedingungen so gewählt, dass sie einen ausreichend homogenen Werkstoff ergeben.

\section{Materialien und Methoden}

Pulvermischungen von etwa $1 \mathrm{~kg}$ Chargenmasse wurden aus einem Basispulver + 4 Masse-\% MA sowie elementarem C als Naturgraphit (Gesamt C-Gehalt der Mischung 0,6 Masse-\%) hergestellt. Die verwendeten Ausgangspulver sind in Tabelle 1 aufgeführt. Die Pulver wurden in einem Turbula-Mischer für 10 min gemischt, gemäß dem Standardverfahren in der Industrie. 


\begin{tabular}{|c|c|c|c|c|}
\hline \multirow{4}{*}{$\begin{array}{l}\text { Table 1. List of starting powders } \\
\text { used in the study. Compositions of } \\
\text { master alloys are nominal.All } \\
\text { compositions in mass\%. Manufac- } \\
\text { turer: Natural graphite (Krop- } \\
\text { fmühl), base powder (Höganäs), } \\
\text { MA (Atomising Systems Ltd.) }\end{array}$} & Code & \multicolumn{3}{|c|}{ Material } \\
\hline & $\mathrm{C}$ & \multicolumn{3}{|c|}{ Natural graphite UF 4} \\
\hline & $\mathrm{Fe}$ & Base powder: & Plain iron. ASC 100.29 & $\mathrm{~d}_{50}: 52.38 \mu \mathrm{m} \pm 3.00 \mu \mathrm{m}$ \\
\hline & Ast85Mo & Base powder: & Fe- $0.85 \mathrm{Mo}$. Astaloy $85 \mathrm{Mo}$ & $\mathrm{d}_{50}: 62.73 \mu \mathrm{m} \pm 1.43 \mu \mathrm{m}$ \\
\hline \multirow{5}{*}{$\begin{array}{r}\text { Tabelle 1. Liste, der in dieser } \\
\text { Studie verwendeten Ausgangspul- } \\
\text { ver. Die Zusammensetzung der } \\
\text { Master Legierungen ist die } \\
\text { Soll-Zusammensetzung.Angaben } \\
\text { in Masse\%. Hersteller: Naturgra- } \\
\text { phit (Kropfmühl), Basispulver } \\
\text { (Höganäs), MA (Atomising } \\
\text { Systems Ltd.) }\end{array}$} & AstCrA & Base powder: & $\mathrm{Fe}-1.8 \mathrm{Cr}$. Astaloy $\mathrm{CrA}$ & $\mathrm{d}_{50}: 64.09 \mu \mathrm{m} \pm 1.24 \mu \mathrm{m}$ \\
\hline & AstCrM & Base powder: & Fe-3.0Cr-0.5Mo. Astaloy CrM & $\mathrm{d}_{50}: 67.89 \mu \mathrm{m} \pm 0.60 \mu \mathrm{m}$ \\
\hline & $\mathrm{H} 45$ & MA: & $\mathrm{Fe} \_32 \mathrm{Cr} \_8 \mathrm{Si} \_4 \mathrm{C}$ & $\mathrm{d}_{50}: 6.80 \mu \mathrm{m} \pm 0.19 \mu \mathrm{m}$ \\
\hline & H46 & MA: & $\mathrm{Fe} \_42 \mathrm{Mn}$ _6Si_0.4C & $\mathrm{d}_{50}: 5.57 \mu \mathrm{m} \pm 0.06 \mu \mathrm{m}$ \\
\hline & $\mathrm{H} 47$ & MA: & $\mathrm{Fe} \_28 \mathrm{Mn} \_27 \mathrm{Cr} \_6 \mathrm{Si} \_3.7 \mathrm{C}$ & $\mathrm{d}_{50}: 6.71 \mu \mathrm{m} \pm 0.10 \mu \mathrm{m}$ \\
\hline
\end{tabular}

wall lubrication using Multical sizing fluid. The green compacts were sintered isothermally at $1300^{\circ} \mathrm{C}$ for $1 \mathrm{~h}$ under defined conditions in an electrically heated furnace with a gas-tight tubular superalloy retort under a high-purity Ar atmosphere for $1 \mathrm{~h}$ and cooled to room temperature in the water-cooled outlet zone of the furnace at about $10 \mathrm{~K} / \mathrm{min}(0.167 \mathrm{~K} / \mathrm{s}$, linearized) within about $120 \mathrm{~min}$.

For the experiments with the quenching dilatometer (Linseis L78Q), parallelepiped pieces $10.4 \times 4 \times 4(\mathrm{~mm})$ were cut from the sintered Charpy specimens. K-type thermocouples were contacted directly onto the sample by spot welding, and 13 measurements were carried out with the same sample (this was feasible because of the low tendency of PM steels to grain coarsening, see [14], and the equally low risk of decarburization in an oxygen-free and esp. dry atmosphere, $\mathrm{H}_{2} \mathrm{O}$ being much more strongly decarburizing than $\mathrm{O}_{2}$ ). The specimen was inductively heated from RT to $900{ }^{\circ} \mathrm{C}$ in $90 \mathrm{~s}$, held for $20 \mathrm{~s}$ and then quenched at the following cooling rates: $90 ; 45 ; 22.5 ; 15 ; 11.25 ; 9 ; 6.4 ; 5 ; 4.5 ; 3 ; 1.5 ; 1$ and $0.75 \mathrm{~K} / \mathrm{s}$. In the $14^{\text {th }}$ run the sample was finally quenched at $3 \mathrm{~K} / \mathrm{s}$ for metallographic examination. These parameters were chosen for the first experiments to avoid overheating of the material. They were retained for reasons of comparability. A further sample was treated directly at a cooling rate of $1.5 \mathrm{~K} / \mathrm{s}$ in a single run. This sample was also examined metallographically to show the influence of the cooling rate on the microstructure and the resulting hardness. High purity, dry $\mathrm{N}_{2}$ (5.0 quality) was used as quenching gas. Although $\mathrm{N}_{2}$ is not really an inert gas, $\mathrm{N}$ uptake by the specimens is very unlikely, since molecular $\mathrm{N}_{2}$ is hardly reactive to sintered iron and steels (and is therefore the main constituent in industrial sintering atmospheres for ferrous PM parts). For metallography the samples were cold embedded in epoxy resin to avoid any additional temperature loads, ground, diamond polished and etched with $1 \%$ Nital. The microhardness HV 0.1 and apparent hardness Vickers HV 30 were measured on the etched samples, in order to make sure that the microhardness indentations were made on the targeted microstructural constituents [15].
Charpy-Schlagbiegeproben nach ISO 5754 wurden mit $600 \mathrm{MPa}$ und Matrizenschmierung verpresst. Als Schmiermittel wurde Kalibrieröl Multical Sizing Fluid verwendet. Die Grünlinge wurden in einem elektrisch beheizten Ofen mit gasdichter Rohrretorte aus Superlegierung unter definierten Bedingungen bei $1300^{\circ} \mathrm{C}$ für $1 \mathrm{~h}$ isotherm unter hochreiner Ar-Atmosphäre gesintert und in der wassergekühlten Auslaufzone des Ofens mit etwa $10 \mathrm{~K} / \mathrm{min}$ $(0,167 \mathrm{~K} / \mathrm{s}$, linearisiert) innerhalb von ca. $120 \mathrm{~min}$ auf Raumtemperatur abgekühlt.

Für die Experimente im Abschreckdilatometer (Linseis L78Q) wurden aus den gesinterten Charpy-Proben quaderförmige Stücke von 10,4 $\times 4 \times 4(\mathrm{~mm})$ geschnitten. Thermoelemente Typ-K wurden durch Punktschweißen direkt auf der Probe kontaktiert. Mit der gleichen Probe wurden jeweils 13 Messungen durchgeführt (dies wurde im Hinblick auf die sehr geringe Neigung von PMStählen zur Kornvergröberung, siehe [14], und das ebenso geringe Risiko der Entkohlung in der $\mathrm{O}_{2}$-freien und vor allem trockenen Atmosphäre für vertretbar gehalten. Der wichtigste Parameter hier ist ein trockenes Gas, da $\mathrm{H}_{2} \mathrm{O}$ deutlich stärker entkohlend wirkt als $\mathrm{O}_{2}$ ). Die Probe wurde in $90 \mathrm{~s}$ induktiv von RT auf $900^{\circ} \mathrm{C}$ erwärmt, die Temperatur für $20 \mathrm{~s}$ gehalten und dann mit den folgenden Abkühlraten abgeschreckt: 90; 45; 22,5; 15; 11,25; 9; 6,4; 5; 4,$5 ; 3 ; 1,5 ; 1$ und $0,75 \mathrm{~K} / \mathrm{s}$. Im 14 . Zyklus wurde die Probe schließlich für metallographische Untersuchungen mit $3 \mathrm{~K} / \mathrm{s}$ abgeschreckt. Diese Parameter wurden für die ersten Experimente gewählt, um ein Überhitzen bzw. Überzeiten des Materials zu vermeiden. Sie wurden aus Vergleichbarkeitsgründen beibehalten. Eine weitere Probe wurde direkt (ohne die 13 Messzyklen davor) mit einer Abkühlgeschwindigkeit von 1,5 K/s behandelt. Diese wurde ebenfalls metallographisch untersucht, um den Einfluss der Abkühlgeschwindigkeit auf das Gefüge und die daraus resultierende Härte darstellen zu können. Als Abschreckgas wurde hochreiner, trockener $\mathrm{N}_{2}$ (5.0 Qualität) verwendet. Obwohl es sich bei $\mathrm{N}_{2}$ um kein echtes Inertgas handelt, wird die Aufnahme von $\mathrm{N}$ in den Proben als sehr unwahrscheinlich erachtet, weil molekularer $\mathrm{N}_{2}$ kaum mit Sintereisen und Sinterstählen reagiert $\left(\mathrm{N}_{2}\right.$ ist daher Hauptbestandteil in industriellen Sinteratmospähren für Fe-PMTeile). Für metallographische Untersuchungen wurde die Probe zur Vermeidung zusätzlicher Temperaturbelastung kalt in Epoxid- 
Table 2 shows the composition of the as sintered specimens. Alloying elements were measured with laser ablation inductively coupled plasma mass spectrometry (LA-ICP-MS, see below) [16] and the $\mathrm{C}$ content was determined by C-LECO measurements (CS230 Carbon/Sulfur Determinator, Co. Leco). The standard used for the latter measurement was a steel pin standard 501-679 with $0.799 \pm 0.011 \mathrm{wt}$.\% C. The strong deviations in the as-sintered C content of the hybrid alloys with master alloy H46 compared to the nominal one are due to the comparatively high oxygen content of this MA and the associated decarburization during sintering.

The LA-ICP-MS analyses were done as follows (data provided by the performing analyst): A Quadrupole ICP-MS iCAP Qc (ThermoFisher Scientific, Bremen, Germany) connected by PTFE tubing of $2 \mathrm{~mm}$ inner diameter with a NWR213 laser ablation system harz eingebettet, geschliffen, diamantpoliert und mit $1 \%$ Nital geätzt. An den geätzten Proben wurden die Mikrohärte HV 0,1 und die Vickers-Makrohärte HV 30 gemessen, um zu gewährleisten, dass die Mikrohärteeindrücke tatsächlich in den gewünschten Gefügebestandteilen gemacht werden können [15].

In Tabelle 2 sind die Zusammensetzungen aller in dieser Studie untersuchten PM-Stähle angeführt. Die Legierungselemente wurden mit laser ablation inductively coupled plasma mass spectrometry (LA-ICP-MS, siehe folgend)[16] bestimmt, die C-Gehalte mithilfe von C-LECO. Als Referenz für die C-LECO wurde ein pin standard 501-679 mit 0,799 $\pm 0,011$ Gew. $\%$ C verwendet. Die starken Abweichungen im C-Gehalt der Hybridlegierungen mit H46 nach dem Sintern im Vergleich zum nominellen C-Gehalt sind auf den vergleichsweise hohen Sauerstoffgehalt dieses MA und den damit verbundenen erhöhten C-Abbrand während des Sinterns zurückzuführen.

Die LA-ICP-MS-Messungen wurden wie folgt durchgeführt (die Daten wurden vom durchführenden Analytiker zur Verfügung gestellt): Für die Messung wurde ein Quadrupole ICP-MS iCAP Qc (ThermoFisher Scientific, Bremen, Deutschland) mit ei-

\begin{tabular}{|c|c|c|c|c|c|c|}
\hline \multirow{2}{*}{ Powder Mix } & \multicolumn{6}{|c|}{ Composition [wt.\%] } \\
\hline & $\mathrm{Fe}$ & $\mathrm{Si}$ & Mn & $\mathrm{Cr}$ & Mo & $\mathrm{C}$ \\
\hline $\mathrm{ASC}+4 \% \mathrm{H} 45$ & 97.87 & 0.39 & 0.16 & 1.09 & 0.01 & 0.49 \\
\hline $\mathrm{ASC}+4 \% \mathrm{H} 46$ & 97.80 & 0.21 & 1.46 & 0.08 & 0.01 & 0.44 \\
\hline $\mathrm{ASC}+4 \% \mathrm{H} 47$ & 97.49 & 0.32 & 0.88 & 0.82 & 0.01 & 0.48 \\
\hline ASC - Ref & 99.33 & 0.00 & 0.13 & 0.05 & 0.01 & 0.49 \\
\hline & $\mathrm{Fe}$ & $\mathrm{Si}$ & Mn & $\mathrm{Cr}$ & Mo & $\mathrm{C}$ \\
\hline Ast $85 \mathrm{Mo}+4 \% \mathrm{H} 45$ & 96.80 & 0.38 & 0.16 & 1.24 & 0.93 & 0.49 \\
\hline Ast $85 \mathrm{Mo}+4 \% \mathrm{H} 46$ & 97.20 & 0.24 & 1.23 & 0.07 & 0.81 & 0.44 \\
\hline Ast85Mo + 4\%H47 & 96.49 & 0.34 & 0.94 & 0.91 & 0.82 & 0.49 \\
\hline Ast85Mo - Ref & 98.48 & 0.00 & 0.17 & 0.05 & 0.84 & 0.47 \\
\hline & $\mathrm{Fe}$ & $\mathrm{Si}$ & Mn & $\mathrm{Cr}$ & Mo & $\mathrm{C}$ \\
\hline Ast $\mathrm{CrA}+4 \% \mathrm{H} 45$ & 96.31 & 0.47 & 0.13 & 2.60 & 0.03 & 0.46 \\
\hline Ast $\mathrm{CrA}+4 \% \mathrm{H} 46$ & 96.16 & 0.31 & 1.44 & 1.65 & 0.03 & 0.42 \\
\hline Ast $\mathrm{CrA}+4 \% \mathrm{H} 47$ & 95.45 & 0.44 & 1.03 & 2.58 & 0.03 & 0.47 \\
\hline Ast CrA - Ref & 97.66 & 0.03 & 0.13 & 1.70 & 0.03 & 0.45 \\
\hline & $\mathrm{Fe}$ & $\mathrm{Si}$ & Mn & $\mathrm{Cr}$ & Mo & $\mathrm{C}$ \\
\hline Ast CrM + 4\% H45 & 94.98 & 0.44 & 0.18 & 3.49 & 0.47 & 0.44 \\
\hline Ast CrM + 4\% H46 & 94.92 & 0.28 & 1.07 & 2.87 & 0.48 & 0.39 \\
\hline Ast $\mathrm{CrM}+4 \% \mathrm{H} 47$ & 94.27 & 0.45 & 0.91 & 3.48 & 0.46 & 0.44 \\
\hline Ast CrM - Ref & 96.33 & 0.03 & 0.15 & 2.59 & 0.46 & 0.44 \\
\hline
\end{tabular}

Table 2. shows the composition of the as sintered steel samples. The alloying element content was determined with LA-ICP-MS, the $\mathrm{C}$ content was determined by C-LECO measurements

Tabelle 2. zeigt die Zusammensetzung der untersuchten Sinterkörper. Die Legierungselemente wurden mit LA-ICP-MS bestimmt, der C-Gehalt wurde mit C-LECO Messungen ermittelt 
(ESI, Fremont, USA), was used. Laser ablation is done under helium flow $(650 \mathrm{~mL} / \mathrm{min})$, argon make up gas is added $(0.85 \mathrm{~L} / \mathrm{min})$ by a concentric mixer. The ICP MS system was calibrated daily for a maximum ${ }^{115}$ In signal with standard SRM-612 (National Institute of Standards \& Technology, Gaithersburg, USA) for trace elements in glass. On each sample three meander ablation patterns were measured (Laser diameter $100 \mu \mathrm{m}$, scan speed $75 \mu \mathrm{m} / \mathrm{s}$, repetition rate $10 \mathrm{~Hz}$, measured area $\sim 0.2 \mathrm{~mm}^{2}$ ). Before measurement a preablation with the same parameters was performed to remove contaminants from the sample surface. Background corrected signals were integrated within the instrument software (Qtegra 2.10) and quantified by linear calibration using the Spectroscopic Standards Nos 401/1-405/1 Low allow steel (Bureau of Analytic Standards Ltd. Newham Hall, England) as standards.

\section{CCT diagrams}

Figure 2 shows the CCT diagrams of the plain base powders (without MA) used in the present studies with a total carbon content of nominally $0.6 \mathrm{wt} . \%$. The respective $\mathrm{C}$ contents after sintering (combined carbon) are shown in brackets on top of the diagrams. It is evident that steels based on plain iron ASC 100.29 and the "lower alloyed" pre-alloyed powders such as Astaloy85 Mo and Astaloy CrA do not sinter harden at the industrially feasible cool- nem Laser-Ablationssystem NWR213 (ESI, Fremont, USA) mit einem PTFE Rohr mit $2 \mathrm{~mm}$ Innendurchmesser verbunden. Die Laser-Ablation wurde unter Heliumfluss $(650 \mathrm{~mL} / \mathrm{min})$ durchgeführt, Ar wurde mit einem konzentrischen Mischer als „make up gas" hinzugemischt $(0,85 \mathrm{~L} / \mathrm{min})$. Das ICP-MS System wird täglich für ein Maximum ${ }^{115}$ In Signal mit dem Standard SRM-612 (National Institute of Standards \& Technology, Gaithersburg, USA) für Spurenelemente in Glas kalibriert. Auf jeder Probe wurden 3 Laser-Ablations-Messungen auf einer mäanderförmigen Messstrecke durchgeführt. (Laserdurchmesser $100 \mu \mathrm{m}$, Scangeschwindigkeit $0,75 \mu \mathrm{m} / \mathrm{s}$, Wiederholungsrate $10 \mathrm{~Hz}$, gemessene Fläche $\sim 0,2 \mathrm{~mm}^{2}$ ). Vor jeder Messung wurden auf der Messstrecke mit den gleichen Parametern Verunreinigungen von der Oberfläche der Probe abgetragen. Backgroundkorrigierte Signale wurden mit Hilfe der Gerätesoftware (Qtegra 2.10) integriert und mit linearer Kalibrierung quantifiziert. Als spektroskopische Standards wurden Nos 401/1-405/1 Low allow steel (Bureau of Analytic Standards Ltd. Newham Hall, England) verwendet.

\section{ZTU-Diagramme}

Bild 2 zeigt die kontinuierlichen ZTU-Diagramme der in dieser Studie verwendeten reinen Basispulver (ohne MA) mit einem Gesamtkohlenstoffgehalt von nominell 0,6 Gew.-\%. Die jeweiligen C-Gehalte nach dem Sintern (gebundener Kohlenstoff) sind oben in den Diagrammen in Klammern angegeben. Es ist offensichtlich, dass Stähle auf Basis von unlegiertem Fe ASC 100.29 und den „niedriger legierten“ vorlegierten Pulvern wie Astaloy85 Mo und
Fig. 2. CCT diagrams of the base powders with $0.6 \% \mathrm{C}$ content (admixed) used in this study (above the diagram: $\mathrm{C}$ content measured after sintering). A) ASC 100.29_0.6C B) Astaloy 85 Mo_0.6C C) Astaloy CrA_0.6C D) Astaloy CrM_0.6C

Bild 2. ZTU-Diagramme der in dieser Studie verwendeten Basispulver mit 0,6 \%C-Gehalt (zugemischt) (über dem Diagramm: C-Gehalt gemessen nach dem Sintern) A) ASC 100.29_0.6C B) Astaloy 85 Mo_0.6C C) Astaloy CrA_0.6C D) Astaloy CrM_0.6C

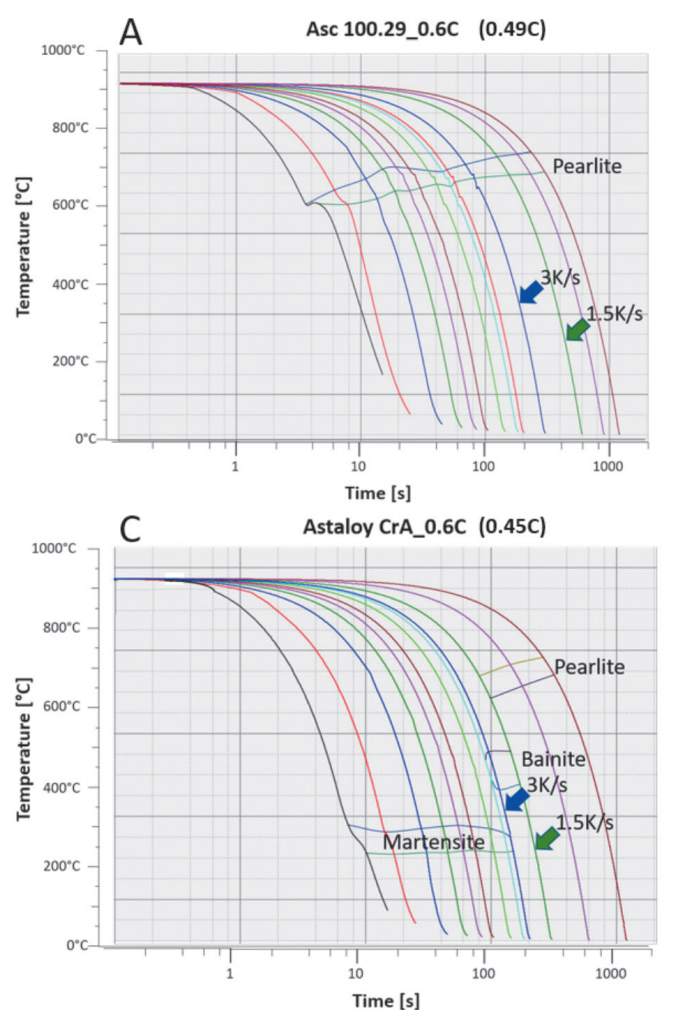

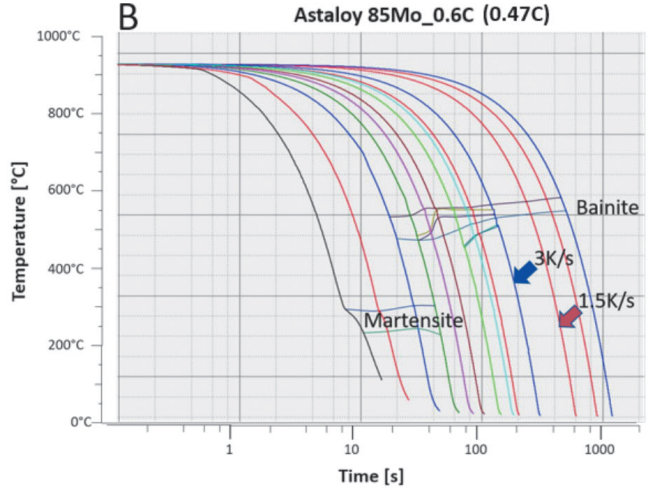

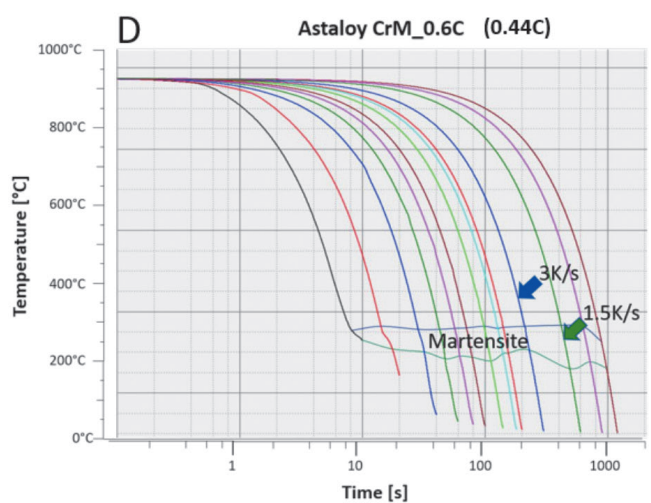



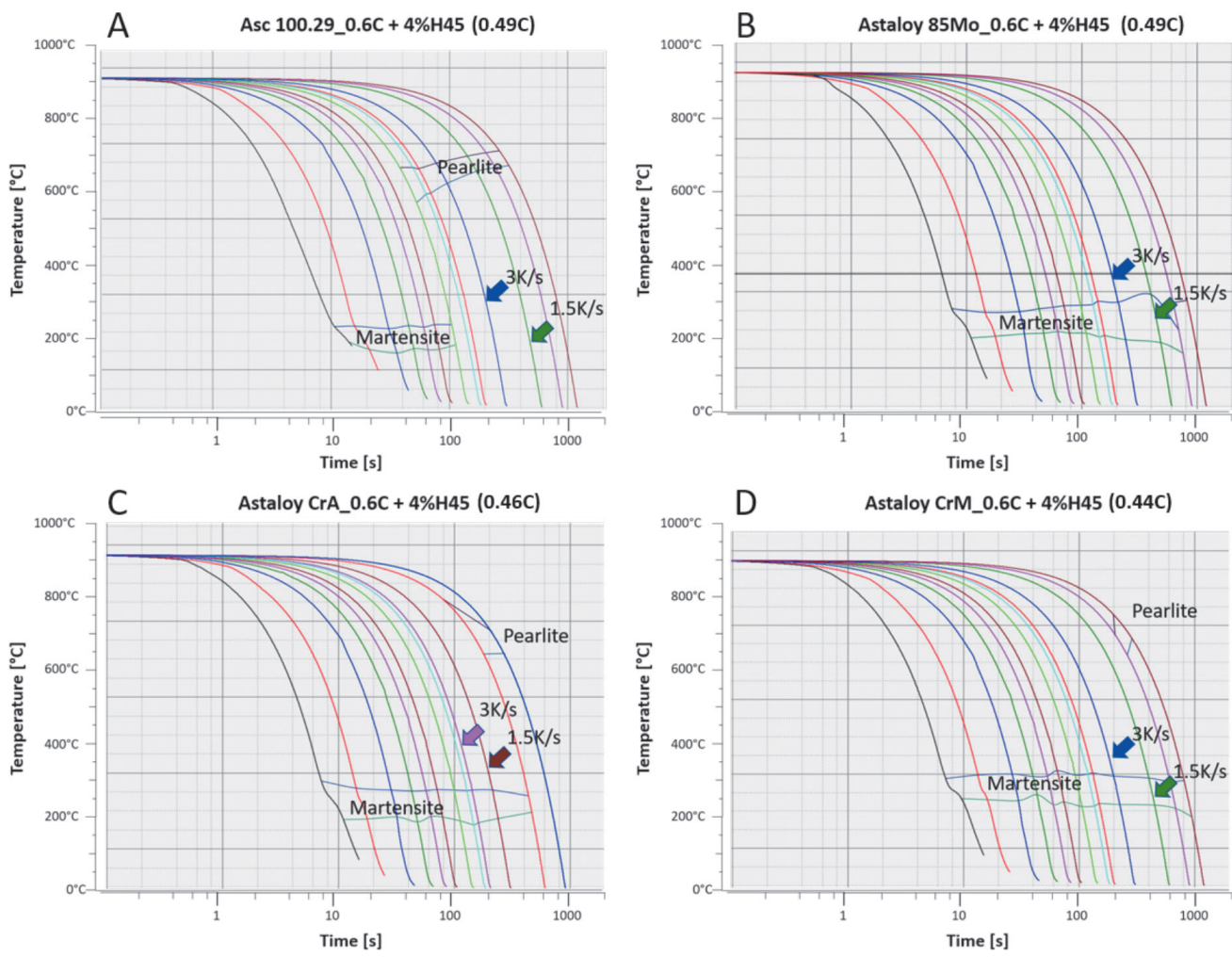

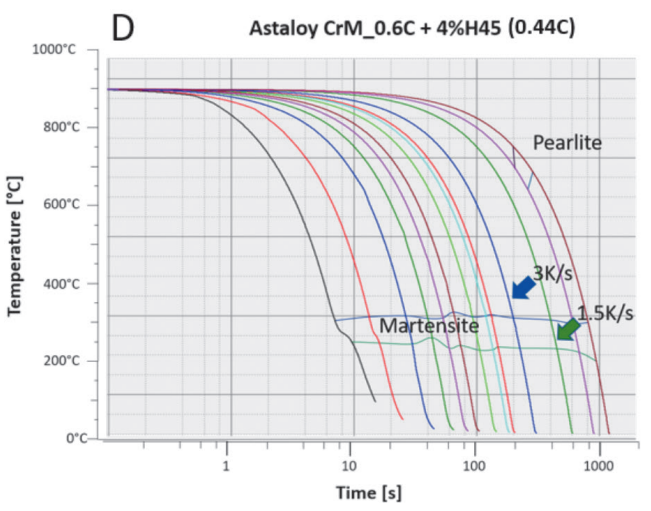

Fig. 3. CCT diagrams of MA H45 $(\mathrm{Cr}-\mathrm{Si})+$ various base powders $(0.6 \% \mathrm{C}$ total in the compact; above the diagram in parentheses: $\mathrm{C}$ content measured after sintering).

A) ASC $100.29+4 \% \mathrm{H} 45-0.6 \mathrm{C}$

B) Astaloy $85 \mathrm{Mo}+4 \% \mathrm{H} 45-0.6 \mathrm{C}$

C) Astaloy $\mathrm{CrA}+4 \% \mathrm{H} 45-0.6 \mathrm{C}$

D) Astaloy $\mathrm{CrM}+4 \% \mathrm{H} 45-0.6 \mathrm{C}$

Bild 3. ZTU-Diagramme von MA H45 (Cr-Si) + verschiedene Basispulver $(0,6 \% \mathrm{C}$ gesamt im Pressling; über dem Diagramm in Klammern: C-Gehalt gemessen nach dem Sintern).

A) ASC $100.29+4 \% \mathrm{H} 45-0.6 \mathrm{C}$

B) Astaloy $85 \mathrm{Mo}+4 \% \mathrm{H} 45-0.6 \mathrm{C}$

C) Astaloy $\mathrm{CrA}+4 \% \mathrm{H} 45-0.6 \mathrm{C}$

D) Astaloy CrM + 4\% $455-0.6 \mathrm{C}$ ing rates, at least at this carbon content. Astaloy CrM can form a martensitic microstructure without any additional alloy elements, as has been previously reported by $G$. Kalss [17]. For all other steel grades, it is clear that additional alloying elements need to be introduced to the material if martensitic hardening at cooling rates common in sinter hardening is desired. Figure 3 shows the CCT diagrams of different base powders $+4 \% \mathrm{H} 45$ (Cr-Si masteralloy). These CCT diagrams are shown here as examples. Similar CCT diagrams were generated with the other base powder + MA combinations.

It is evident that sintered steels made of plain Fe base powder ASC 100.29, at least with the carbon content chosen here, cannot be hardened under standard sinter hardening conditions, even when combined with a MA, except for H47 (Mn-Cr-Si master alloy) (see Chapter 4). In contrast, hybrid alloyed powder mixes can be sinter hardened to martensite at cooling rates of $1.5 \mathrm{~K} / \mathrm{s}$, sometimes even lower. This means that, with the carbon contents considered in this study, master alloys should be combined with a pre-alloyed powder (hybrid alloying) if martensitic sinter hardening is desired. Although it is possible to achieve a martensitic microstructure in Astaloy CrM without MA, the combination with MA results in an even higher macro- and microhardness. Figure $3 \mathrm{D}$ shows the CCT diagram of the hybrid powder mix $\mathrm{CrM}+4 \% \mathrm{H} 45$. Comparing this diagram with the CCT diagram of the CrM pre-alloyed powder without MA shown in Figure 2D, it is observed that at cooling rates of $1 \mathrm{~K} / \mathrm{s}$ and $0.75 \mathrm{~K} / \mathrm{s}$ a pearlite formation takes place in the hybrid alloyed material, which is not ob-
Astaloy CrA zumindest bei diesem Kohlenstoffgehalt bei den industriellen Standard-Abkühlraten nicht sinterhärten. Astaloy CrM kann, wie bereits von $G$. Kalss [17] berichtet, ohne zusätzliche Legierungselemente ein martensitisches Gefüge ausbilden. Für alle anderen Stahlsorten ist klar, dass zusätzliche Legierungselemente in den Werkstoff eingebracht werden müssen, wenn eine martensitische Härtung mit den beim Sinterhärten üblichen Abkühlgeschwindigkeiten angestrebt wird. In Bild 3 sieht man die ZTU-Diagramme der verschiedenen Basispulver + 4\%H45 (Cr-SiMasteralloy). Diese ZTU-Diagramme werden hier beispielsweise gezeigt. Analoge ZTU-Diagramme wurden mit den anderen Basispulvern + MA-Kombinationen erstellt.

Es ist klar ersichtlich, dass Sinterstahl aus reinem Fe-Basispulver ASC 100.29 zumindest mit dem hier gewählten Kohlenstoffgehalt unter Standard-Sinterhärtungsbedingungen nicht gehärtet werden kann, selbst wenn es mit einer Master Alloy kombiniert wird, außer mit H47 (Mn-Cr-Si-Masteralloy) (siehe Kapitel 4). Bei den hybridlegierten Pulvermischungen kann eine Sinterhärtung zu Martensit dagegen bis zu Abkühlgeschwindigkeiten von 1,5 K/s, manchmal sogar darunter, erreicht werden. Dies bedeutet, dass bei den in dieser Studie gewählten Kohlenstoffgehalten Master Alloys mit vorlegierten Pulvern kombiniert werden sollten, wenn eine martensitische Sinterhärtung erwünscht ist. Obwohl es bei Astaloy CrM möglich ist, auch ohne MA ein martensitisches Gefüge zu erreichen, führt die Kombination mit MA zu einer noch höheren Makro- und Mikrohärte. Das Bild 3D zeigt das ZTU-Diagramm der hybridlegierten Mischung $\mathrm{CrM}+4 \% \mathrm{H} 45$. Vergleicht man das Diagramm mit dem in Bild 2D gezeigten ZTU-Diagramm des vorlegierten Pulvers CrM ohne Master Alloy, so kann man 
served in the pure pre-alloyed powder. The reason for this finding is that heat treatment at $900{ }^{\circ} \mathrm{C}$ for $20 \mathrm{~s}$ may not be sufficient to completely dissolve carbides in the material and thus less dissolved $\mathrm{C}$ is available in the austenite matrix than nominally should be present. This observation is discussed in more detail in chapter 5 .

\section{Microstructure}

Figure 4 shows the CCT diagram of ASC $100.29+4 \% H 47$ (Mn-CrSi masteralloy) and the microstructure of the material for different quenching parameters. In agreement with the CCT diagram, the martensitic transformation ( $775 \mathrm{HV} 0.1)$ dominates at $3 \mathrm{~K} / \mathrm{s}$, while at $1.5 \mathrm{~K} / \mathrm{s}$ a martensitic - pearlitic microstructure is formed. Some areas show a significantly higher microhardness ( 695 HV 0.1) compared to the pearlitic microstructure ( $270 \mathrm{HV} \mathrm{0.1).} \mathrm{This} \mathrm{is}$ also consistent with the cooling curve for a cooling rate of $1.5 \mathrm{~K} / \mathrm{s}$, which is shown in the CCT diagram. The as sintered sample has a homogeneous pearlitic microstructure. Figure 4B shows that even after cooling at $3 \mathrm{~K} / \mathrm{s}$ the microstructure is not fully martensitic, some pearlitic areas could still be obtained. These areas are most likely the cores of larger base powder particles which were not sufficiently alloyed during sintering. However, the formation of these pearlitic areas could not be observed in the CTT diagram, which indicates that their volume fraction is rather low. feststellen, dass bei dem hybridlegierten Material bei Kühlraten von $1 \mathrm{~K} / \mathrm{s}$ und $0,75 \mathrm{~K} / \mathrm{s}$ eine Perlitbildung stattfindet, die bei dem reinen vorlegierten Pulver nicht festzustellen ist. Der Grund dafür ist, dass mit hoher Wahrscheinlichkeit die Austenitisierungsparameter $900{ }^{\circ} \mathrm{C}$ für $20 \mathrm{~s}$ nicht ausreichen, um karbidische Bestandteile des Materials vollständig zu lösen und somit weniger im Austenit gelöster $\mathrm{C} \mathrm{zu}$ Verfügung steht, als nominell vorhanden sein sollte. Diese Beobachtung wird in Kapitel 5 näher ausgeführt.

\section{Gefüge}

Bild 4 zeigt das ZTU-Diagramm des Sinterstahls ASC 100.29 + 4\%H47 (Mn-Cr-Si Master Alloy) und die Mikrostruktur des Materials für verschiedene Abschreckparameter. In Übereinstimmung mit dem ZTU-Diagramm dominiert bei $3 \mathrm{~K} / \mathrm{s}$ die martensitische Umwandlung ( $775 \mathrm{HV}$ 0,1), während sich bei $1,5 \mathrm{~K} / \mathrm{s}$ ein martensitisch-perlitisches Gefüge ausbildet. Einige Bereiche zeigen eine signifikant höhere Mikrohärte ( 695 HV 0,1) im Vergleich zur perlitischen Mikrostruktur ( 270 HV 0,1). Das stimmt auch mit der Abkühlkurve bei einer Kühlrate von 1,5 K/s überein, die im ZTU-Diagramm dargestellt ist. Die gesinterte, nicht abgeschreckte Probe zeigt ein homogenes perlitisches Gefüge. Des Weiteren sieht man in Bild 4B, dass nach dem Abkühlen mit $3 \mathrm{~K} / \mathrm{s}$ das Gefüge nicht vollständig martensitisch ist, es konnten noch einige perlitische Bereiche gefunden werden. Bei diesen Bereichen handelt es sich höchstwahrscheinlich um die Kerne größerer Basispulverpartikel, die während des Sinterns nicht ausreichend legiert wurden. Die Bildung dieser perlitischen Bereiche

Fig. 4. PM steel Fe (ASC 100.29)

$+4 \% \mathrm{MA} \mathrm{H} 47$ (Mn-Cr-Si)

A) CCT diagram

B) Microstructure

quenched at $3 \mathrm{~K} / \mathrm{s}$

C) Microstructure

quenched at $1.5 \mathrm{~K} / \mathrm{s}$

D) Microstructure after sintering
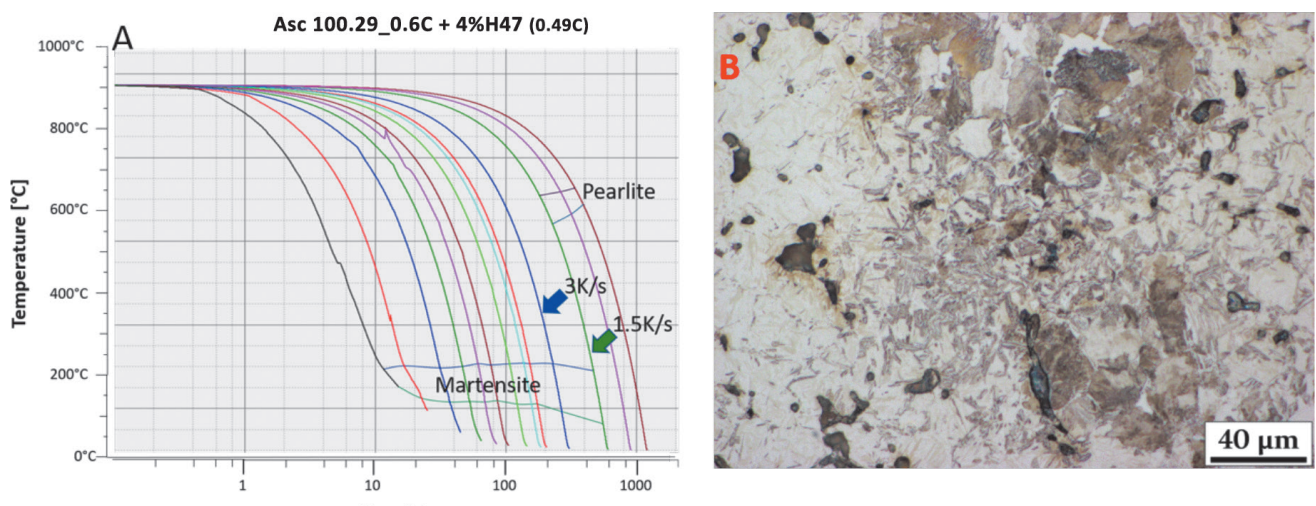

Bild 4. PM-Stahl Fe (ASC 100.29)

$+4 \% \mathrm{MA} \mathrm{H} 47$ (Mn-Cr-Si)

A) ZTU-Diagramm

B) Gefüge abgeschreckt mit $3 \mathrm{~K} / \mathrm{s}$

C) Gefüge abgeschreckt mit $1,5 \mathrm{~K} / \mathrm{s}$

D) Mikrostruktur nach dem Sintern
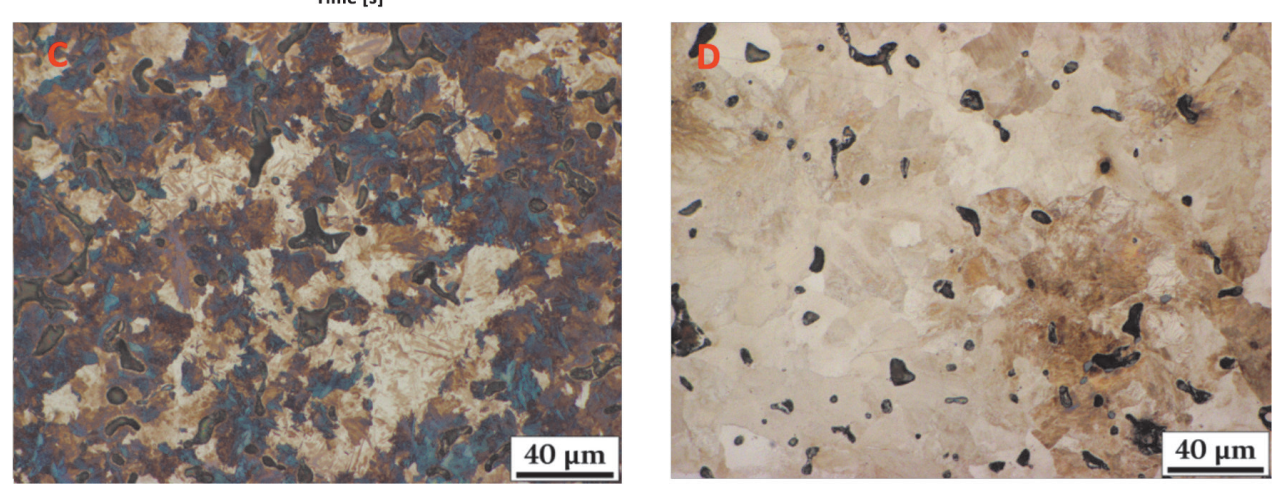

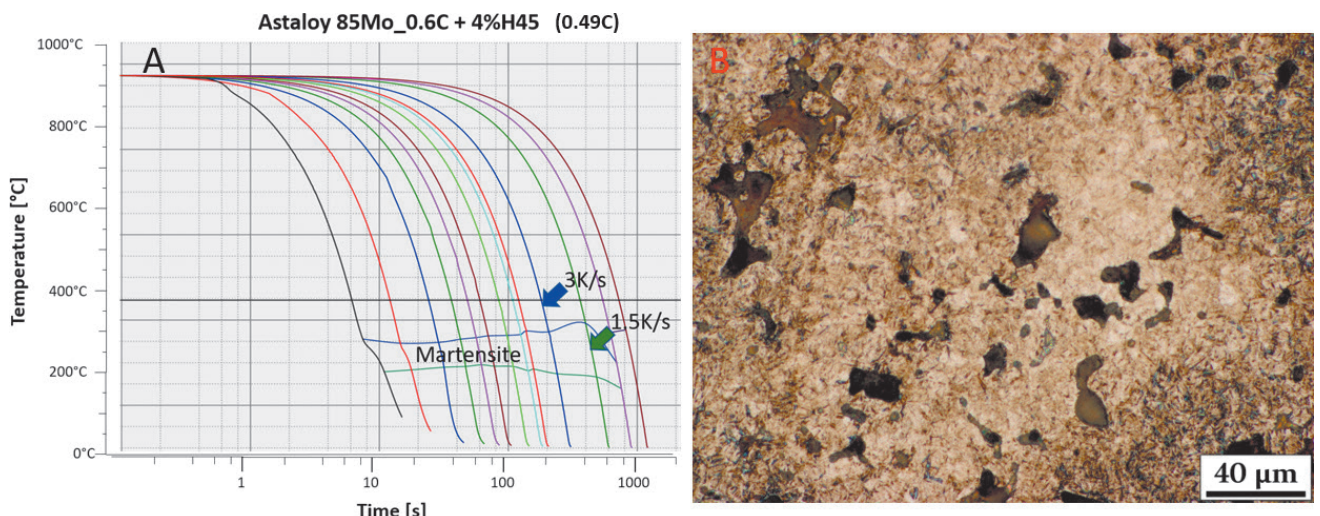

Fig. 5. PM steel Astaloy85Mo + 4\%MA H45 (Cr-Si):

A) CCT diagram

B) Microstructure

quenched at $3 \mathrm{~K} / \mathrm{s}$

C) Microstructure

quenched at $1.5 \mathrm{~K} / \mathrm{s}$

D) Microstructure after sintering
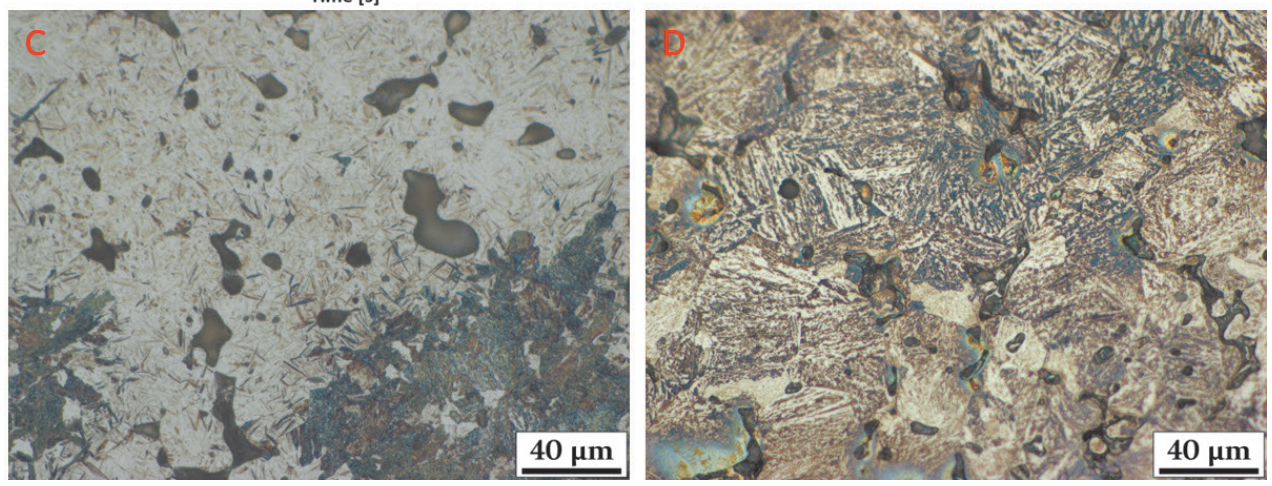

Bild 5. PM-Stahl Astaloy85Mo + 4\%MA H45 (Cr-Si):

A) ZTU-Diagramm

B) Gefüge abgeschreckt

mit $3 \mathrm{~K} / \mathrm{s}$

C) Gefüge abgeschreckt

mit $1,5 \mathrm{~K} / \mathrm{s}$

D) Gefüge nach dem Sintern

Hybrid alloying of MA + Astaloy85Mo was the first step to increase hardenability. As shown in Figure 5, this hybrid approach turns out to be sufficient to enable martensitic hardening even at lower cooling rates compared to ASC 100.29. At $3 \mathrm{~K} / \mathrm{s}$ cooling rate a uniform fine martensitic microstructure $(\sim 730 \mathrm{HV} 0.1)$ was achieved with the combination Ast $85 \mathrm{Mo}+4 \% \mathrm{H} 45$. If this material is cooled at $1.5 \mathrm{~K} / \mathrm{s}$ the microstructure is similar to ASC $100.29+4 \%$ H47: a fine martensite $(\sim 700$ HV 0.1$)$ with pearlitic areas ( $\sim 298 \mathrm{HV} 0.1)$ is formed. Most likely, these pearlitic areas once more originate from large base powder particles. In terms of hardenability there is a clear improvement from ASC 100.29 to Astaloy85Mo, where all hybrid alloyed mixes from Astaloy 85 achieved a martensitic hardening with $3 \mathrm{~K} / \mathrm{s}$, although this is not always completely homogeneous. Even if the influence of microstructural inhomogeneities is not as pronounced, a homogeneous microstructure is more desirable, especially with regard to fatigue properties and wear resistance. Fully homogeneous martensitic microstructures could be achieved with all hybrid alloyed powder mixes based on Astaloy $\mathrm{CrM}$, both at $3 \mathrm{~K} / \mathrm{s}$ and $1.5 \mathrm{~K} / \mathrm{s}$, respectively. Figure 6 shows Astaloy $\mathrm{CrM}+4 \% \mathrm{H} 46$, the CCT diagram and the microstructures for the different cooling rates. At $3 \mathrm{~K} / \mathrm{s}$ and $1.5 \mathrm{~K} / \mathrm{s}$ a very fine martensitic microstructure was formed. The as sintered sample showed a lower bainite microstructure. konnte jedoch im ZTU-Diagramm nicht beobachtet werden, was darauf hinweist, dass ihr Volumenanteil eher gering ist.

Die hybridlegierten Pulvermischungen aus $\mathrm{MA}+$ Astaloy85 Mo waren der erste Schritt zur Erhöhung der Härtbarkeit. Wie in Bild 5 gezeigt, reicht die Zugabe von MA zu einem mit $0,85 \%$ Mo vorlegierten Basispulver aus, um eine martensitische Härtung auch bei geringeren Abkühlgeschwindigkeiten im Vergleich zu Reineisen-Basispulver zu ermöglichen. Bei $3 \mathrm{~K} / \mathrm{s}$ Kühlrate wurde mit der Kombination Astaloy85Mo $+4 \% \mathrm{H} 45$ ein einheitliches feines martensitisches Gefüge ( $730 \mathrm{HV} 0,1)$ erreicht. Kühlt man dieses Material mit 1,5 K/s ab, ist das Gefüge ähnlich wie bei ASC $100.29+4 \% \mathrm{H} 47$, es bildet sich ein feiner Martensit $(\sim 700 \mathrm{HV} 0,1)$ mit perlitischen Bereichen ( $298 \mathrm{HV} 0,1)$. Höchstwahrscheinlich stammen diese wiederum aus großen Basispulverpartikeln, deren Kerne ohne die zusätzlichen Legierungselemente aus dem MA nicht ausreichend härtbar sind. Hinsichtlich der Härtbarkeit gibt es eine deutliche Verbesserung von ASC 100.29 zu Astaloy85Mo, wo alle hybridlegierten Kombinationen auf Basis von Astaloy85Mo zu einem martensitischen Gefüge führen, das allerdings nicht immer vollständig homogen ist. Auch wenn der Einfluss mikrostruktureller Inhomogenitäten nicht so stark ausgeprägt ist, ist ein homogenes Gefüge wünschenswerter, insbesondere hinsichtlich Ermüdungseigenschaften und Verschleißfestigkeit. Vollständig homogene martensitische Gefüge konnten mit hybridlegierten Pulvern auf Basis von Astaloy CrM erreicht werden, sowohl mit $3 \mathrm{~K} / \mathrm{s}$ als auch mit 1,5 K/s. Bild 6 zeigt Astaloy $\mathrm{CrM}+4 \% \mathrm{H} 46$, das ZTU-Diagramm und die Gefüge für die verschiedenen Abkühlraten. Bei $3 \mathrm{~K} / \mathrm{s}$ und $1,5 \mathrm{~K} / \mathrm{s}$ bildete sich ein sehr feines martensitisches Gefüge aus. 
Fig. 6. PM steel Astaloy CrM + 4\%MA H46 (Mn-Si):

A) ZTU diagram

B) Microstructure quenched at $3 \mathrm{~K} / \mathrm{s}$

C) Microstructure quenched at $1.5 \mathrm{~K} / \mathrm{s}$

D) Microstructure after sintering
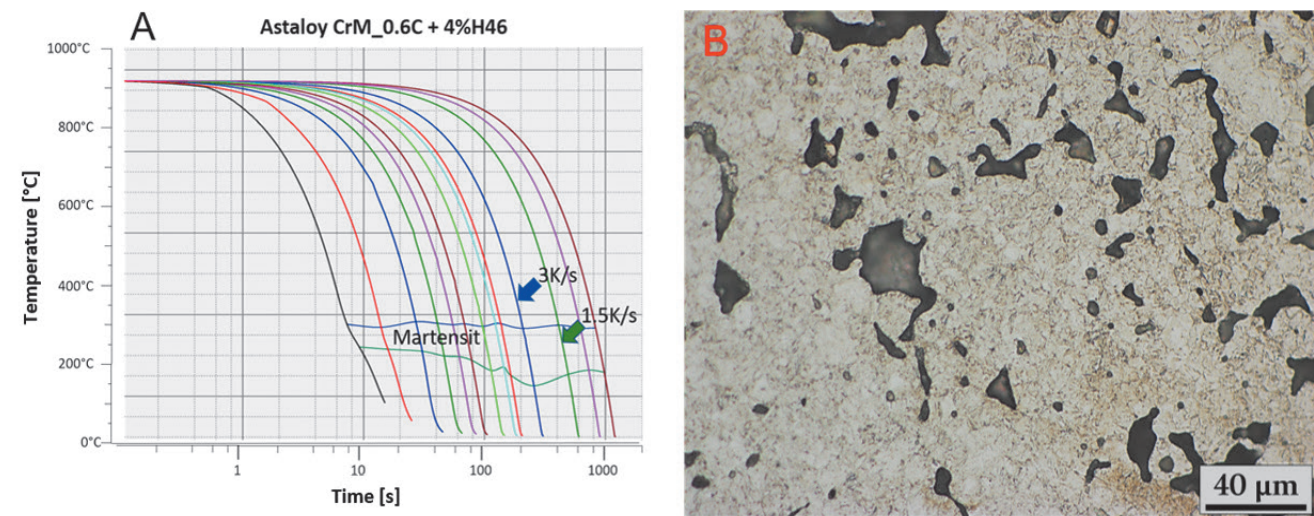

Bild 6. PM-Stahl Astaloy CrM + 4\%MA H46 (Mn-Si): A) ZTU-Diagramm

B) Gefüge abgeschreckt mit $3 \mathrm{~K} / \mathrm{s}$

C) Gefüge abgeschreckt mit $1,5 \mathrm{~K} / \mathrm{s}$

D) Mikrostruktur nach dem Sintern
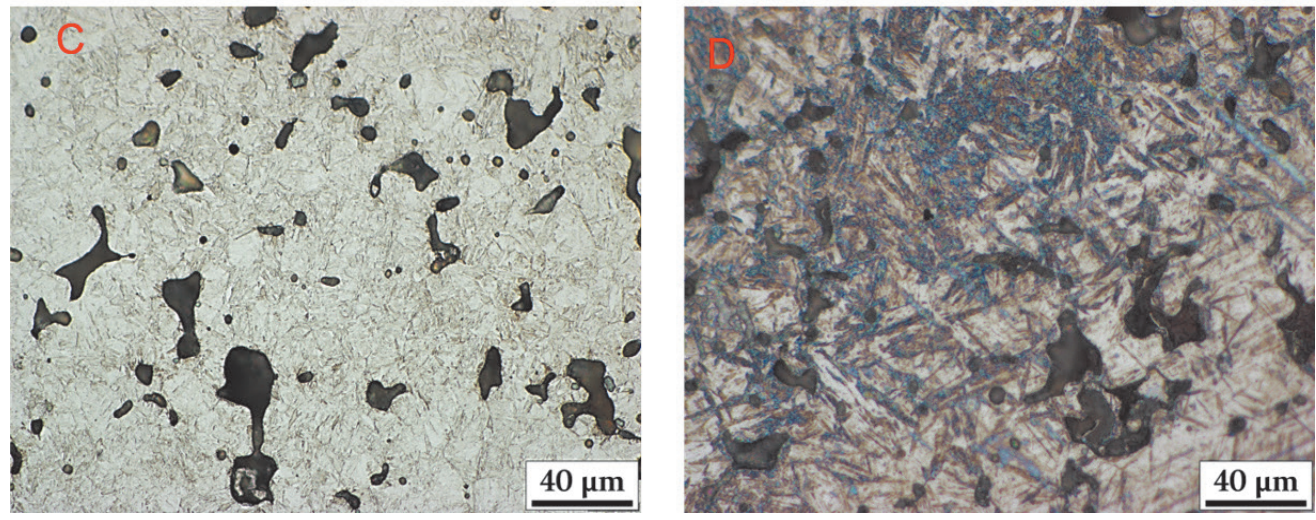

These results show that the hybrid alloying, meaning the combination of moderate $\mathrm{Cr}$ and low Mo contents added through pre-alloying with further alloy elements introduced through the MA route, is a highly effective way to enhance the hardenability of sintered steels even at the moderate cooling rates typical for industrial sinter hardening.

\section{Hardness}

To determine the hardness of the specimens, values for HV 30 (depicted in Figure 7) and HV 0.1 (Figure 8) were recorded, to obtain both the hardness of the metallic matrix and the "integral" or apparent hardness; the latter includes the effect of porosity. For the micro-hardness measurements, 14 indentations were evaluated per sample. The shapes of the indentations were optically checked to verify whether a pore affected the indentation. If this was the case, a new measurement at another location was taken. For an inhomogeneous microstructure, seven indentations were made in each of the different microstructural constitutents. The micro-hardness values shown in the bar charts in Figure 8 are the averaged values of all indentations to give a feeling for the inhomogeneity of the hardness by means of the standard deviation bar.
Die gesinterte Probe, die nicht abgeschreckt wurde, zeigte das Gefüge von unterem Bainit.

Diese Ergebnisse zeigen, dass die Hybridlegierungstechnik, also die Kombination von vorlegiert eingebrachten mäßigen $\mathrm{Cr}$ und niedrigen Mo- Gehalten mit weiteren Legierungselementen, die über die Master Alloy-Route eingebracht werden, ein sehr effektiver Weg ist, um die Härtbarkeit von Sinterstählen selbst bei den für die industrielle Sinterhärtung typischen moderaten Abkühlraten zu verbessern.

\section{Härtemessungen}

Zur Bestimmung der Härte der Proben wurden Werte für HV 30 (dargestellt in Bild 7) und HV 0,1 (Bild 8) gemessen, um sowohl die Härte der metallischen Matrix als auch die Makrohärte als „integrale“ Härte (apparent hardness) zu erhalten, wobei letztere auch den Effekt der Porosität einschließt. Für die Mikrohärtemessung wurden pro Probe 14 Eindrücke ausgewertet. Die Eindrücke wurden optisch durch ihre Gestalt überprüft, ob beim Eindruck auf eine Pore gedrückt wurde, diese Werte wurden gegebenenfalls verworfen und durch ein erneutes Messen an einer anderen Stelle ersetzt. Im Falle eines inhomogenen Gefüges wurden jeweils sieben Eindrücke in den unterschiedlichen Gefügebestandteilen gemacht. Die Mikrohärtewerte, die in den Balkendiagrammen in Bild 8 gezeigt werden, sind jeweils die gemittelten Werte aller Eindrücke, um mit Hilfe des Standard- 

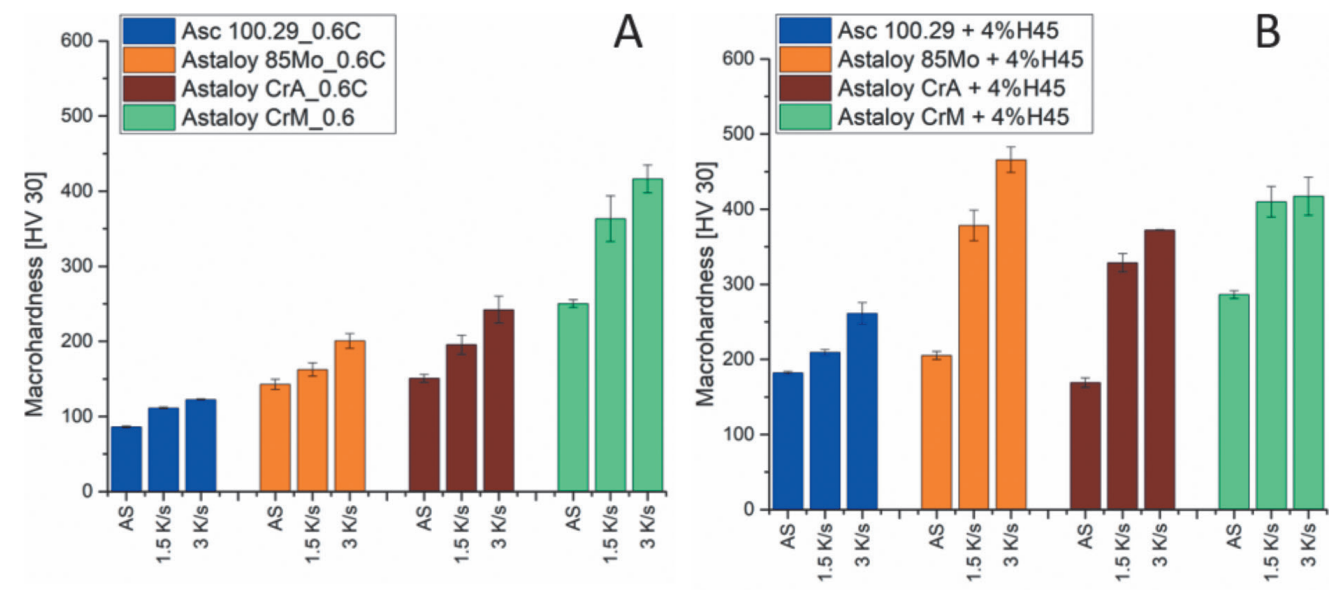

Fig. 7. Macro hardness HV 30 of sintered steels after different heat treatments.

A) Base powder without MA

B) Base powder $+4 \% \mathrm{H} 45$

C) Base powder $+4 \% \mathrm{H} 46$

D) Base powder

$+4 \% \mathrm{H} 47.0 .6 \% \mathrm{C}$ nominal, compacted at $600 \mathrm{MPa}$, sintered $60 \mathrm{~min}$ at $1300^{\circ} \mathrm{C}$ in $\mathrm{Ar}$
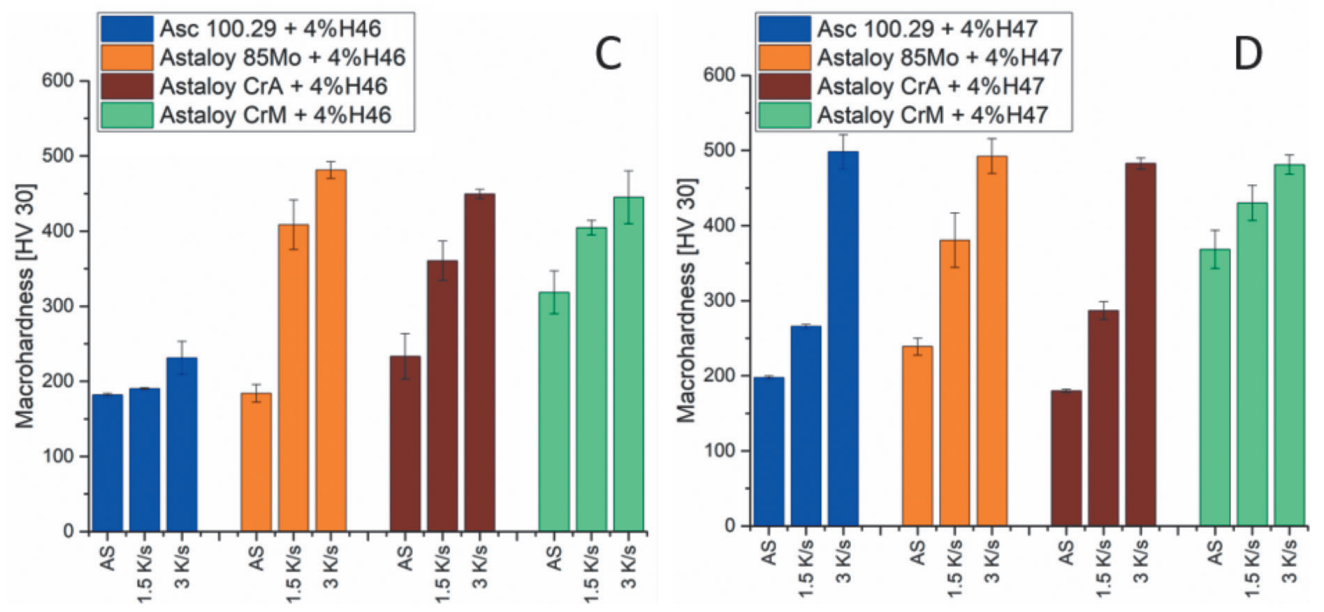

Bild 7. Makrohärte HV 30 von gesinterten Stählen nach verschiedenen Wärmebehandlungen

A) Basispulver ohne MA

B) Basispulver $+4 \% \mathrm{H} 45$

C) Basispulver $+4 \% \mathrm{H} 46$

D) Basispulver $+4 \% \mathrm{H} 47$. 0,6\% C nominell, verdichtet bei $600 \mathrm{MPa}$, gesintert 60 min bei $1300^{\circ} \mathrm{C}$ in $\mathrm{Ar}$

Figure 7 shows HV 30 of the reference samples prepared from the base powders ASC 100.29, Astaloy85 Mo, Astaloy CrA and Astaloy CrM without MA as well as the respective materials with the MAs H45(Cr-Si MA), H46(Mn-Si MA) and H47(Mn-Cr-Si MA). In general, as expected from the CCT diagrams as well as the microstructures, the hybrid alloying technique leads to significantly better hardness values. At a cooling rate of $3 \mathrm{~K} / \mathrm{s}, \mathrm{H} 47$ in combination with plain iron ASC 100.29 forms a hard microstructure that can compete with samples prepared from pre-alloyed powder, although it showed a heterogeneous microstructure. Surprisingly, the combination MA + Astaloy85Mo achieved even higher hardness levels than $\mathrm{MA}+$ Astaloy CrM or Astaloy CrA. A possible explanation for this is that the heat-treating profile used for the samples, especially the austenitizing conditions, might be closer to the optimum for MA + Astaloy 85. This means that the MAs were originally designed for combination with plain Fe base powder, and the heat treatment conditions used were originally intended for the combination MA + ASC 100.29. The austenitizing temperature strongly depends on the alloying elements [18] which leads to the assumption that the Cr-containing pre-alloyed base powders Astaloy $\mathrm{CrA}$ and $\mathrm{CrM}$ require a higher austenitizing tem- abweichungsbalken ein Gefühl für die Inhomogenität der Härte zu vermitteln.

Bild 7 zeigt die HV 30-Werte der aus den Basispulvern ASC 100.29, Astaloy85 Mo, Astaloy CrA und Astaloy CrM ohne MA hergestellten Referenzproben sowie die jeweiligen Werkstoffe mit den Masterlegierungen H45(Cr-Si-MA), H46(Mn-SiMA) und H47(Mn-Cr-Si MA). Wie aus den ZTU-Diagrammen sowie den Mikrostrukturen zu erwarten war, führt die Hybridlegierungstechnik zu einer deutlich besseren Härte. Bei einer Abkühlgeschwindigkeit von $3 \mathrm{~K} / \mathrm{s}$ bildet $\mathrm{H} 47$ in Kombination mit reinem Fe ASC 100.29 ein Gefüge aus, das härtemäßig mit den aus vorlegiertem Pulver hergestellten Proben konkurrierte, obwohl es ein heterogenes Gefüge zeigte. Überraschenderweise erreichte die Kombination MA + Astaloy85 Mo sogar höhere Härtegrade als MA + Astaloy CrM oder CrA. Eine mögliche Erklärung dafür ist, dass das für die Proben verwendete Wärmebehandlungsprofil, insbesondere die Austenitisierungsbedingungen, näher am Optimum für $\mathrm{MA}+$ Astaloy85 Mo liegen könnte. Das bedeutet, dass die MAs ursprünglich für die Kombination mit reinem Fe-Basispulver konzipiert wurden und ebenso die verwendeten Wärmebehandlungsbedingungen ursprünglich für die Kombination MA + ASC 100.29 gedacht war. Die Austenitisierungstemperatur hängt stark von den Legie- 
Fig. 8. Microhardness HV 0.1 of sintered steels after different heat treatments.

A) Base powder without MA

B) Base powder $+4 \% \mathrm{H} 45$

C) Base powder $+4 \% \mathrm{H} 46$

D) Base powder + 4\% $447.0 .6 \% \mathrm{C}$ nominal, compacted at $600 \mathrm{MPa}$, sintered $60 \mathrm{~min}$ at $1300^{\circ} \mathrm{C}$ in $\mathrm{Ar}$
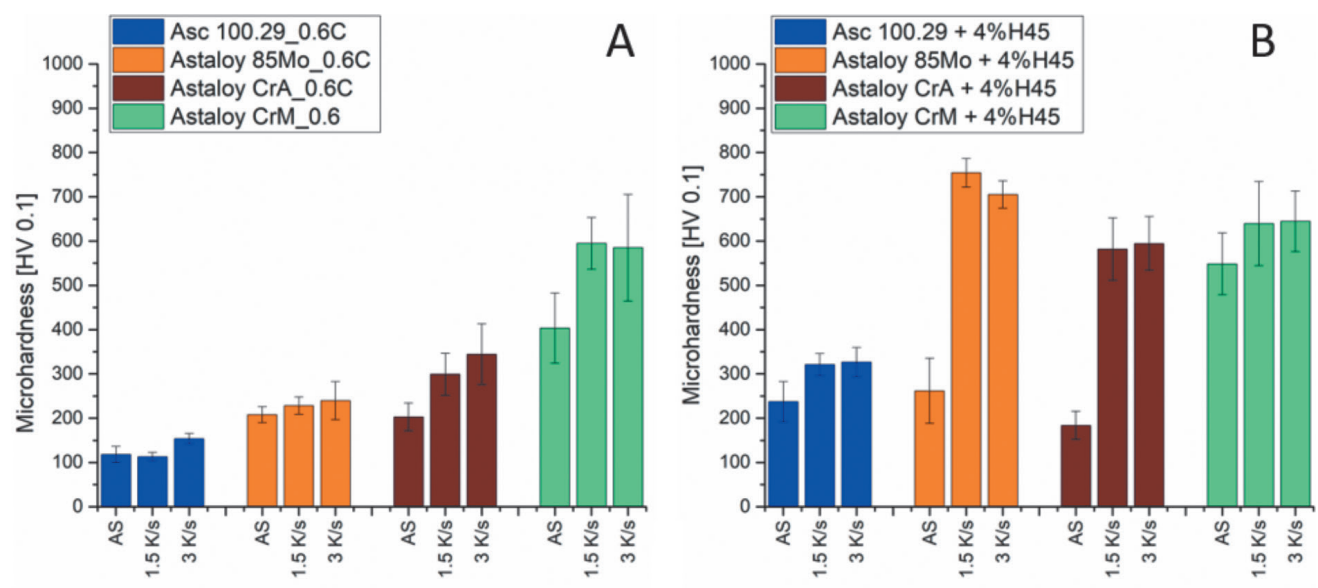

Bild 8. Mikrohärte HV 0,1 von gesinterten Stählen nach verschiedenen Wärmebehandlungen.

A) Basispulver ohne MA

B) Basispulver $+4 \% \mathrm{H} 45$

C) Basispulver $+4 \% \mathrm{H} 46$

D) Basispulver + 4\%H47. 0,6\%C nominell, verdichtet bei $600 \mathrm{MPa}$ gesintert $60 \mathrm{~min}$ bei $1300^{\circ} \mathrm{C}$ in $\mathrm{Ar}$
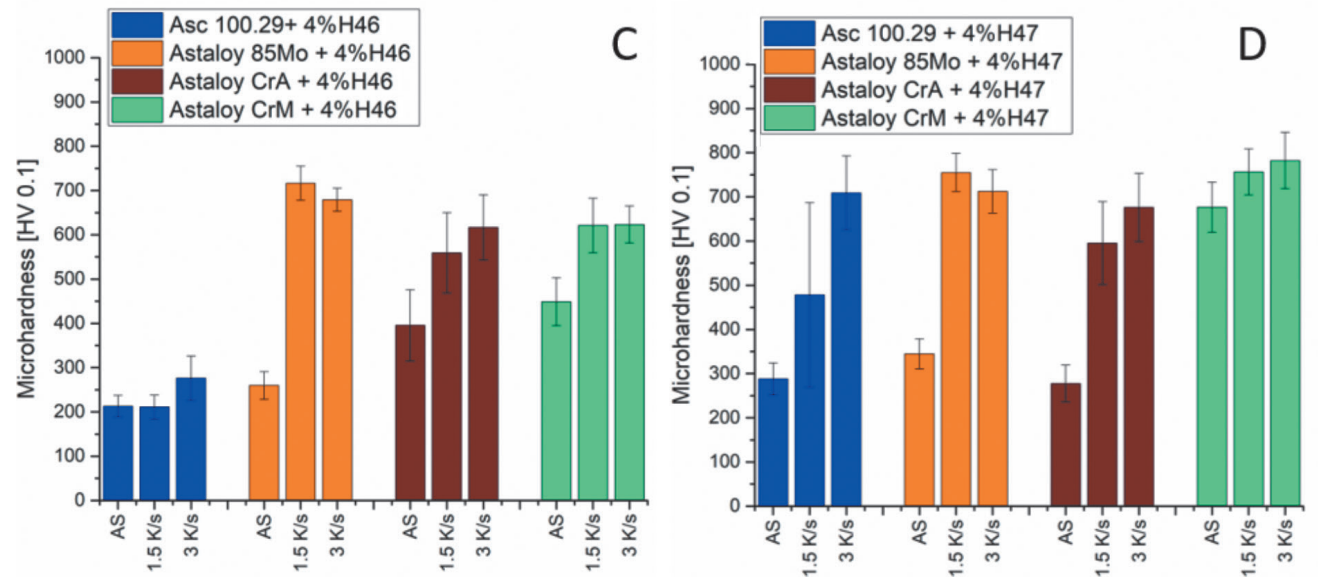

perature, whereas the base powder pre-alloyed only with Mo can be hardened well at lower temperatures.

When comparing the hardness data for Astaloy CrM_0.6 with the values reported by G. Kalss [17], it is noticeable that higher hardness values were reported in [15]. One reason for this might be that austenitizing for $20 \mathrm{~s}$ at $900{ }^{\circ} \mathrm{C}$ is insufficient for this material. Therefore, the heat treatment was modified, whereby the specimens were austenitized for $300 \mathrm{~s}$ at $1100^{\circ} \mathrm{C}$ (which is analogous to the parameters in [15] and is also closer to the conditions of industrial sinter hardening) and cooled again at $3 \mathrm{~K} / \mathrm{s}$ and $1.5 \mathrm{~K} / \mathrm{s}$, respectively. In this short study, the sample cooled at $3 \mathrm{~K} / \mathrm{s}$ was a single run as well. As shown in Figure 9, the heat treatment with higher temperature and longer holding time in fact further improved the hardness of the material at $3 \mathrm{~K} / \mathrm{s}$ cooling rate, which indicates indeed that temperatures $>900^{\circ} \mathrm{C}$ and longer times are required to dissolve the carbides in Astaloy $\mathrm{CrM}$.

The clearest indication of this can be found in the martensite start temperatures $\left(\mathrm{M}_{\mathrm{s}}\right)$, which can be taken from the CCT diagrams. Comparing the measured temperatures with the calculations in rungselementen ab [18], was die Vermutung zulässt, dass die Cr-haltigen vorlegierten Basispulver Astaloy CrA und CrM eine höhere Austenitisierungstemperatur benötigen, wohingegen das nur mit Mo vorlegierte Basispulver mit weniger hohen Temperaturen gut härtbar ist.

Beim Vergleich der hier für Astaloy CrM_0,6C gemessenen Härten mit den von G. Kalss [17] angegebenen Werten fällt auf, dass in [17] höhere Härten angegeben werden. Ein Grund dafür könnte sein, dass das Austenitisieren für $20 \mathrm{~s}$ bei $900{ }^{\circ} \mathrm{C}$ für diesen Werkstoff unzureichend ist. Deshalb wurde die Wärmebehandlung modifiziert, wobei die Proben für $300 \mathrm{~s}$ bei $1100^{\circ} \mathrm{C}$ austenitisiert (analog zu den Parametern in [17], was auch den Bedingungen beim industriellen Sinterhärten ohnehin näher kommt) und wieder mit $3 \mathrm{~K} / \mathrm{s}$ bzw. 1,5 K/s abgekühlt wurden. In dieser kurzen Studie wurde die Probe mit $3 \mathrm{~K} / \mathrm{s}$ ebenfalls nur mit einem Abkühlvorgang erstellt. Wie in Bild 9 dargestellt, wurde durch die Wärmebehandlung mit höherer Temperatur und längerer Haltezeit die Härte des Werkstoffs mit $3 \mathrm{~K} / \mathrm{s}$ Kühlrate tatsächlich weiter verbessert, was darauf hindeutet, dass, wie vermutet, Temperaturen $>900^{\circ} \mathrm{C}$ und auch längere Zeiten erforderlich sind, um die Karbide im Astaloy CrM aufzulösen.

Den deutlichsten Hinweis dafür findet man in den MartensitStarttemperaturen $\left(\mathrm{M}_{\mathrm{s}}\right)$, die aus den ZTU-Diagrammen zu entnehmen sind. Vergleicht man die gemessenen Temperaturen mit 


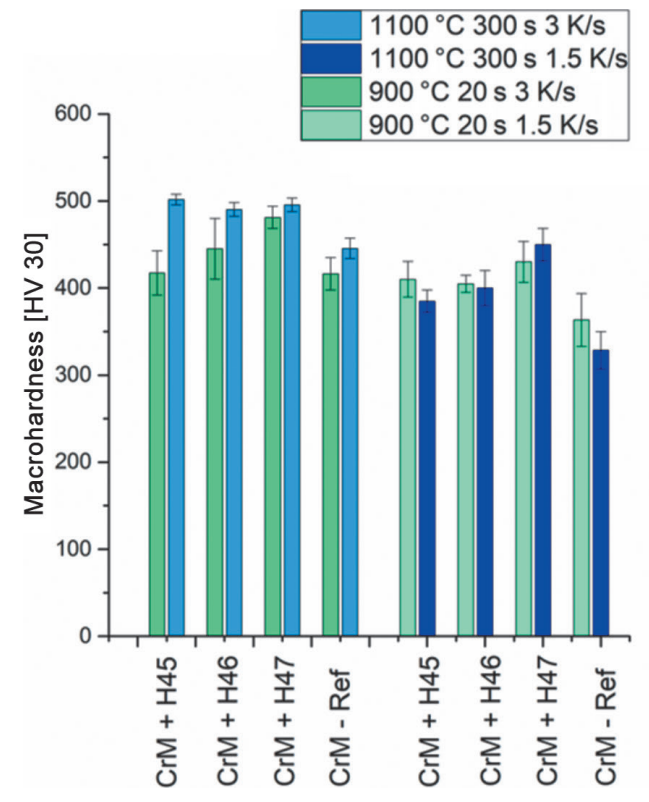

[19] from Steven and Haynes, it is observed that with the higher temperatures and longer holding times, the $\mathrm{M}_{\mathrm{s}}$ temperatures of measurement and calculation agree very well, whereas for the original temperature-time profile the measured $\mathrm{M}_{\mathrm{s}}$ temperature was significantly higher than that predicted from the calculation. This can actually only be explained by the fact that some $\mathrm{C}$, most likely in the form of carbides, is present in bonded form and not dissolved in the matrix. Especially for the Cr containing MA H45 the improvement was significant.

However, as stated above, even very high austenitizing temperatures are no problem for PM-materials, since the pores inhibit grain growth in a very early stage [14]; even sinter hardening from $1250{ }^{\circ} \mathrm{C}$ proved to be successful [20]. The microstructure of CrM-Ref with different temperature profiles is shown in Figure 10. The hardness could be increased from 416 HV 30 (585 HV 0.1) to $446 \mathrm{HV} 30$ (760 HV 0.1) with the new austenitizing parameters. den Berechnungen in [19], von Steven und Haynes, so kann man feststellen, dass mit den höheren Temperaturen und längeren Haltezeiten die $\mathrm{M}_{\mathrm{s}}$-Temperaturen von Messung und Berechnung sehr gut übereinstimmen, wohingegen bei dem ursprünglichen Temperatur-Zeitprofil die gemessene $\mathrm{M}_{\mathrm{s}}$-Temperatur deutlich höher als die Berechnung lag. Die lässt sich eigentlich nur damit erklären, dass bei $900^{\circ} \mathrm{C}$ noch etwas $C$, höchstwahrscheinlich in Form von Karbiden gebunden, vorliegt. Besonders bei dem Cr-haltigen MA H45 war die Verbesserung signifikant.

Wie oben erwähnt, sind aber selbst sehr hohe Austenitisierungstemperaturen für PM-Werkstoffe kein Problem, da die Poren das Kornwachstum in einem sehr frühen Stadium hemmen [14]. Selbst die Sinterhärtung von $1250^{\circ} \mathrm{C}$ erwies sich als erfolgreich [20]. Die Mikrostruktur von CrM-Ref mit unterschiedlichen Temperaturprofilen wird in Bild 10 gezeigt. Mit den neuen Austenitisierungsparametern konnte die Härte von 416 HV $30(585$ HV 0,1) auf $446 \mathrm{HV} 30$ (760 HV 0,1) erhöht werden.
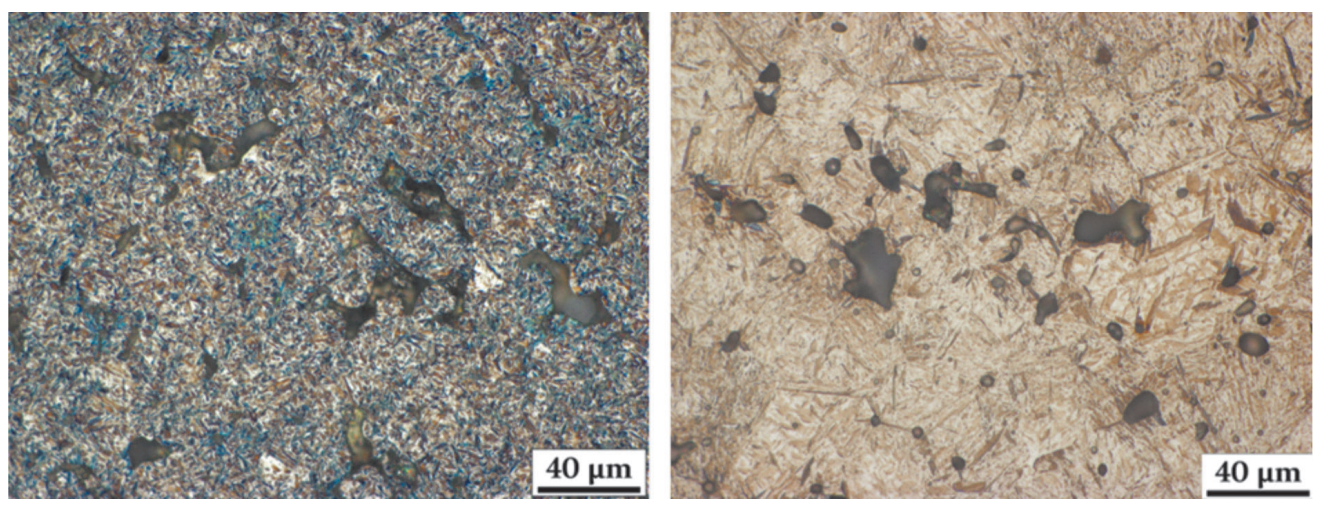

Fig. 10. Microstructure of CrM-Ref (without masteralloy) $900^{\circ} \mathrm{C}$ for $20 \mathrm{~s}$ cooled at $3 \mathrm{~K} / \mathrm{s}$ (left) CrM Ref $1100^{\circ} \mathrm{C}$ for $300 \mathrm{~s}$ cooled at $3 \mathrm{~K} / \mathrm{s}$ (right)

Bild 10. Gefüge von CrM-Ref (ohne Masteralloy) $900^{\circ} \mathrm{C}$ für $20 \mathrm{~s}$ gekühlt mit $3 \mathrm{~K} / \mathrm{s}$ (links) CrM Ref $1100^{\circ} \mathrm{C}$ für $300 \mathrm{~s}$ gekühlt mit $3 \mathrm{~K} / \mathrm{s}$ (rechts) 


\section{Conclusions}

- The hybrid alloying technique, meaning the combination of master alloys and pre-alloyed base powder, significantly improves the hardenability compared to steels made from plain Fe-base powder.

- CCT diagrams of PM-steel were generated and correlated to the microstructure of quenched samples.

- Martensitic hardening of plain Fe-base powder could be achieved at $3 \mathrm{~K} / \mathrm{s}$ and a master alloy of the type Fe-Mn-Cr-Si-C.

- Using a $0.85 \%$ Mo pre-alloyed base powder combined with master alloys leads to hybrid alloyed mixes with high hardness and good hardenability.

- Fully martensitic homogeneous microstructures could be achieved with all hybrid alloyed materials using Astaloy CrM as base powder.

- CrM based materials show the smallest hardness differences for cooling rates of 3 and $1.5 \mathrm{~K} / \mathrm{s}$, respectively, i. e. these steels are most robust in sinter hardening.

- Both for apparent hardness and microhardness, the type of base powder is more important than the selection of the master alloy, at least with the MA types investigated here.

- Improved austenitizing conditions, approximating those in industrial sinter hardening, were tested for Astaloy CrM + 4\% MA and resulted in considerably increased hardness of the materials.

- Further experiments with different heating profiles might optimize the hardenability of the different combinations.

\section{Acknowledgements}

The authors would like to thank Atomising Systems Ltd, Sheffield, UK, for producing the Master Alloy powders used in this study.

Our special thanks go to Project Assistant Dipl.-Ing. Maximilian Weiss, BSc for carrying out the LA-ICP-MS measurements.

\section{Zusammenfassung}

- Der Hybridlegierungsansatz, also die Kombinationen von Master Alloy und vorlegiertem Basispulver, verbessert die Härtbarkeit im Vergleich zu Stählen aus reinem Fe-Basispulver erheblich.

- ZTU-Diagramme von verschiedenen PM-Stählen wurden erstellt und mit der Mikrostruktur von abgeschreckten Proben korreliert.

- Die martensitische Härtung eines einfachen Fe-Basispulvers konnte nur bei $3 \mathrm{~K} / \mathrm{s}$ und einem Masteralloy vom Typ Fe-Mn-CrSi-C erreicht werden.

- Die Verwendung eines mit 0,85 \%Mo vorlegierten Pulvers ergab hybridlegiert in Kombination mit allen Masteralloys gutes Sinterhärteverhalten und hohe Härten.

- Bei Verwendung von Cr-Mo-vorlegiertem Astaloy CrM als Basispulver konnte hybridlegiert mit allen Master Alloys ein vollständig homogenes martensitisches Gefüge erzielt werden.

- Werkstoffe auf CrM-Basis zeigen die geringsten Härteunterschiede bei Abkühlgeschwindigkeiten von 3 bzw. 1,5 K/s, das heißt, diese Stähle sind beim Sinterhärten am robustesten.

- Sowohl für die Makrohärte als auch für die Mikrohärte ist die Art des Basispulvers wichtiger als die Auswahl des Master Alloys, zumindest bei den hier untersuchten MA-Typen.

- Verbesserte Austenitisierungsbedingungen, vergleichbar denen beim industriellen Sinterhärten, wurden für Astaloy $\mathrm{CrM}+4 \% \mathrm{MA}$ getestet, was zu erheblich erhöhten Härten der Werkstoffe führte.

- Weitere Experimente mit verschiedenen Erwärmungsprofilen könnten die Härtbarkeit der verschiedenen Kombinationen optimieren.

\section{Danksagung}

Die AutorInnen danken Fa. Atomising Systems Ltd., Sheffield, UK, für die Herstellung der verwendeten Master Alloy-Pulver.

Besonderer Dank gilt Projektassistent Dipl.-Ing. Maximilian Weiss, BSc für die Durchführung der LA-ICP-MS Messungen. 


\section{References}

1. Danninger, H.; De Oro Calderon, R.; Gierl-Mayer, C.: Alloy Systems for Heat Treated Sintered Steels. HTM J. of Heat Treatm. and Mat. 74 (2019) 5, pp. 282-292, DOI:10.3139/105.110394

2. Danninger, H.; Gierl, C.: Processes in PM steel compacts during the initial stages of sintering. Mater. Chem. Physics. 67 (2001) 1, pp. 49-55, DOI:0.1016/S02540584(00)00419-3

3. Mardan, M.; Blais, C: Development of Novel Pre-alloyed PM Steels for Optimization of Machinability and Fatigue Resistance of PM Components. J. mat. eng. perform. 25 (2016), pp. 764-773, DOI:10.1007/s11665-016-1900-3

4. Höganäs: Iron and steel powders of sintered components. Höganäs Handbook for sintered components. Höganäs, Sweden, 2017. - ISBN: 978-91-983614-0-7

5. Zapf, G.; Dalal, K.: Introduction of high oxygen affinity elements manganese, chromium, and vanadium in the powder metallurgy of P/M parts. Modern Develop. Powder Metall. 10 (1977), pp. 129-152

6. Castro Pinto, F.; Sarasola, M.; Baumgaertner, F.; Dougan, M.; Mitchell, S.; Lipp, K.; Bender, H.; Coffin, C.; Dunkley, J.: Alloying and sintering behaviour of selected irongraphite-master alloy powder mixtures. Proc. Powder metallurgy congress \& exhibition. 2.-5.10.2005, Prag, EPMA, Shrewsbury, 2005, 371-378. - ISBN: 1-89907-218-7

7. Zhang, Z.; Sandström, R.: Fe-Mn-Si master alloy steel by powder metallurgy processing. J. Alloys Comp. 363 (2004) 1-2, pp. 199-207, DOI:10.1016/S09258388(03)00462-6

8. Zhang, Z.; Frisk, K.; Salwén, A.; Sandström, R.: Mechanical properties of Fe-MoMn-Si-C sintered steels. Powder Metall. 47 (2004) 3, pp. 239-246, DOI:10.1179/ 003258904225015572

9. Klein, A. N.; Oberacker R.; Thümmler, F.: High-Strength Si-Mn-Alloyed Sintered Steels - Microstructure and Mechanical-Properties. Powder Metall. Int. 17 (1985) 1, pp. 13-16

10. Vattur Sundaram, M.; Surreddi, K. B.; Hryha, E.; Veiga, A.; Berg, S.; Castro, F; Nyborg, L.: Enhanced Densification of PM Steels by Liquid Phase Sintering with Boron-Containing Master Alloy. Metall. Mat. Trans. A. 49 (2018) 1, pp. 255-263, DOI:10.1007/s11661-017-4383-4

11. de Oro Calderon, R., Dunkley, J.; Gierl, C.; Danninger, H.: New opportunities for master alloys: Ultra-high pressure water atomised powders. Powder Metall. Review 8 (2019) 1, pp. 55-66

12. Geroldinger, S.: Optimization of iron-based Master Alloys for liquid phase sintering of PM steels. Master Thesis, TU Wien, 2019
13. Lindskog, P.: The history of Distaloy. Powder Metall. 56 (2013) 5, pp. 351-361, DOI:10.1179/1743290113Y.0000000077

14. Dlapka, M.; Strobl, S.; Gierl-Mayer, C.; Huemer. M.; Danninger, H.: Austenitkorngröße in gesinterten pulvermetallurgischen Stählen/Austenite grain size in sinter hardened powder metallurgy steels. Practical Metall. 47 (2010) 12, pp. 686-699

15. Gierl, C.; Danninger, H.: Thermal Analysis of Plain Iron - The Effect of „Inert“ Atmospheres. Proc. Powder metallurgy congress \& exhibition. 2.-5.10.2005, Prag, EPMA, Shrewsbury, 2005, pp. 3-8

16. Limbeck, A.; Bonta, M.; Nischkauer, W.: Improvements in the direct analysis of advanced materials using ICP-based measurement techniques. J. Analytical Atomic Spectrom. 32 (2017) 2, pp. 212-232, DOI:10.1039/C6JA00335D

17. Kalss, G.: Sinterhärten von Cr-Mo-legierten PM-Stählen für hochbelastbare Präzisionsteile. Dissertation, TU Wien, 2007, p. 321

18. Krauss, G.: Steels: processing, structure, and performance. ASM International, Ohio, 2015, p. 705. - ISBN: 978-0871708175

19. Steven, W.; Haynes, A. G.: The Temperature of Formation of Martensite and Bainite in Low-alloy Steel. J. of the iron and steel institute 183 (1956), pp. 349-359

20. Maroli, B.; Sigurd, B.; Peter, T.; Engström, U.: Sinter - Hardening and heat treatment of materials based on Astaloy. Proc. Advances in powder metallurgy and particulate materials. 8.-12.06.2003, Las Vegas, Metal Powder Industries Federation, Princeton, 2003. - ISBN 9781878954961

21. Šalak, A.: Ferrous Powder Metallurgy. Cambridge International Science Pub., Cambridge, 1995, p. 170. - ISBN 9781898326038

22. Lindskog, P.F.; Bocchini, G. F.: Development of High Strength P/M Precision Components in Europe. Int. J. Powder Metall. \& Powder Techn. 15 (1979) 3, pp. 198-320

\section{Bibliography}

DOI:10.1515/htm-2020-0007

HTM J. Heat Treatm. Mat.

76 (2021) 2; page 105-119

(c) 2021 Walter de Gruyter GmbH, Berlin/Boston, Germany

ISSN 1867-2493, e-ISSN 2194-1831 